\title{
Missing the Marks: Dispersion in Corporate Bond Valuations Across Mutual Funds*t
}

\author{
Gjergji Cici \\ Assistant Professor of Finance \\ Mason School of Business \\ College of William \& Mary \\ Williamsburg, VA 23187 USA \\ 757-221-1826 gjergji.cici@mason.wm.edu \\ Scott Gibson \\ Associate Professor of Finance \\ Mason School of Business \\ College of William \& Mary \\ Williamsburg, VA 23187 USA \\ 757-221-1673 scott.gibson@ mason.wm.edu \\ John J. Merrick, Jr. \\ Richard S. Reynolds Associate Professor of Business \\ Mason School of Business \\ College of William \& Mary \\ Williamsburg, VA 23187 USA \\ 757-221-2721 john.merrick@mason.wm.edu
}

First Draft: November 2007

This Draft: July 15, 2008

\footnotetext{
*The authors thank Elliot Levine and Andres Vinelli of FINRA; Sean Collins, Brian Reid and Gregory Smith of the Investment Company Institute; and Kenneth Volpert of Vanguard for helpful background discussions. We also thank our discussants and other participants at our presentations at the Financial Industry Regulatory Authority in Washington, DC, the 2008 Financial Management Association European Meetings in Prague, and the 2008 Western Finance Association Meetings in Waikoloa, Hawaii, including Dion Bongaerts, Patrick Herbst, Hsienhsing Liao and Jeff Pontiff.

$\dagger$ This paper received the Society of Quantitative Analysts Award for best paper in quantitative investments at the 2008 Western Finance Association Meetings.
} 


\begin{abstract}
We study the dispersion of month-end valuations placed on identical corporate bonds by different mutual funds. Our dispersion measures offer insights into corporate bond valuation problems at the individual security level. Results show that pricing dispersion is related to bond-specific characteristics typically associated with market liquidity and market-wide volatility. We show that the rollout of FINRA's transparencyenhancing TRACE system has increased the precision of corporate bond valuation, benefiting investors. We also find that the volatile marking patterns of some funds are associated with return smoothing behavior. However, return smoothing behavior is not prevalent across our sample of bond mutual funds.
\end{abstract}


How hard is it to mark illiquid securities for position valuation purposes? As it happens, the issue of accurate marks on the securities positions held by banks, hedge funds and mutual funds has become a focal point for company boards and regulators and made front-page news in the financial press during the credit crisis of 2007. Senior executives of major investment firms have resigned in the midst of significantly revised write-downs of illiquid structured financial product asset values. ${ }^{1}$ The SEC is examining how accurately mutual funds and other investors "value their hard-to-value" securities. ${ }^{2}$ Furthermore, an investment adviser and several of its employees recently agreed to settle SEC charges that they negligently mispriced certain bonds owned by two high-yield municipal bond funds in a way which caused prices for these funds' shares to be artificially high. ${ }^{3}$ Thus, problems regarding the accurate pricing of securities are not confined to esoteric instruments and have direct implications for both asset allocation and the integrity of the investment process. ${ }^{4}$

Our paper analyzes important aspects of US corporate bond pricing and related issues in bond market structure and transparency by examining the dispersion of monthend valuations simultaneously placed on identical bonds by an important set of traders: the managers of US bond mutual funds. A mutual fund's manager must value the fund's bond holdings for net asset value (NAV) purposes. A mutual fund's net asset value sets the day's terms at which fund shares may be purchased and redeemed. A fund should ensure that its daily NAV is fairly valued. An unfairly valued NAV can result in dilution of shareholder interests or other harm to shareholders. Thus, funds should strive to price their individual securities based upon an unbiased and reliable perception of their respective current values in order to ensure fairness for fund share trading.

\footnotetext{
${ }^{1}$ For example, Stanley O'Neal of Merrill Lynch and Charles Prince of Citigroup each resigned after initial firm estimates of asset write-downs due to the sub-prime credit crisis proved to be substantially understated.

${ }^{2}$ As reported in Pulliam, Smith and Siconolfi (2007).

${ }^{3}$ See the SEC's actions versus Heartland Advisors Inc. (http://www.sec.gov/litigation/admin/2008/338884.pdf). Heartland's funds "invested primarily in non-rated, medium and lower quality municipal bonds. The majority of the municipal bonds owned by the Funds were below investment grade and illiquid. Market quotations were not readily available for most of the bonds owned by the Funds. From March 1, 2000 into October 2000, the Funds' portfolios included several municipal bonds that were valued by the Funds at prices above their fair values. As a result, on numerous days throughout that time period, the Funds' Net Asset Values ("NAVs") were incorrect, the Funds' shares were incorrectly priced, and investors purchased and redeemed Fund shares at prices that benefited redeeming investors at the expense of remaining and new investors."

${ }^{4}$ See Pulliam (2007).
} 
But as the credit crisis of 2007 has called into question, the accurate pricing of individual bond holdings is not always a simple matter. In fact, our study revolves around examining discrepancies in the price marks that different mutual funds simultaneously place on identical bond issues. Our data allow us to test how corporate bond valuation precision may be affected by variables thought to be related to market liquidity - e.g., issue size and credit rating - as well as any other bond-specific characteristic such as time to maturity. We also examine the trade reporting initiative instituted by the Financial Industry Regulatory Authority's (FINRA) Trade Reporting and Compliance Engine (TRACE) system for collecting corporate bond trade details from dealers and disseminating corporate bond transaction price information. We test whether the increased market transparency due to the staged rollout of TRACE has reduced crossfund bond price dispersion in an economically meaningful way. ${ }^{5}$ Thus, our study has practical value for a diverse group of stakeholders, including bond trading firms, fund managers, fund investors and regulators.

Fundamentally, our mutual fund bond valuation data allow us to explore the difficulty of assessing the current market values of illiquid securities. While illiquid, corporate bonds are much less opaque than the structured financial products like the Collateralized Debt Obligations that lay at the heart of the 2007 credit crisis. Thus, our evidence documenting the difficulties regarding precise assessment of corporate bond market value is all the more compelling.

Our study makes four contributions. It is the first study to directly measure how difficult it is to mark positions in the over-the-counter corporate bond market. Furthermore, our focus on the cross-fund dispersion of a given corporate bond's valuation offers direct insight into potential NAV calculation problems at the individual security level. Related research has previously offered only indirect assessments of the difficulty of marking securities positions for mutual fund NAV purposes by examining the staleness of closing prices on exchange-traded equities (see, for example, Chalmers, Edelen and Kadlec, (2001)) as well as "return smoothing" behavior by hedge funds based

\footnotetext{
${ }^{5}$ The rollout of TRACE began in July 2002 under the auspices of the NASD (National Association of Securities Dealers) to improve corporate bond transparency. FINRA was formed through the consolidation of NASD and the member regulation, enforcement and arbitration functions of the New York Stock Exchange in July 2007.
} 
upon serial correlation patterns in security prices and fund returns (see Asness, Krail and Liew (2001), Bollen and Pool (2006) and Getmansky, Lo and Makarov (2004)). In contrast, we directly analyze the dispersion of internal marks on identical bonds placed by mutual funds managers. Second, we find clear evidence that the rollout of TRACE has decreased cross-fund bond price dispersion even for bonds that were not initially included in the list of reporting securities. Previous research has found that TRACE has decreased the trade execution costs of corporate bond trading. Our results here suggest that the TRACE-induced increase in corporate bond market transparency has benefited the market more generally by increasing bond valuation precision. Third, we also uncover and analyze some systematic differences in bond holdings valuations that appear to incorporate the impact of differences in fund bid versus mid bond value marking standards. Finally, while we confirm that most funds appear to follow reasonably consistent pricing policies, our tests also identify certain funds with volatile marking practices that seem to be associated with return smoothing behavior. This final investigation adapts a variant of Getmansky, Lo and Makarov's (2004) framework to search for serial correlation in fund returns after incorporating a "remarked-at-consensusprices" fund portfolio to measure the economic return on any particular fund's holdings.

Some students of equity markets and equity mutual funds may already be puzzled with our focus on the dispersion of month-end prices on identical bonds. Unlike equities, the overwhelming majority of bond trading takes place in over-the-counter dealer markets instead of on centralized exchanges. Thus, bond mutual funds do not share common access to a single exchange-determined closing price for each individual bond issue. $^{6}$ For some issues, this lack of an exchange-determined closing price is not an important impediment to valuing a fund's holding. For example, trading in each of the most recently auctioned (on-the-run) US Treasury securities is highly liquid and very transparent. Dealer-to-dealer and dealer-to-customer electronic trading platforms and the ubiquitous Bloomberg terminal offer continuous pictures of bid and offered prices for these securities. In stark contrast, most high-yield corporate bond issues trade infrequently in thin, illiquid markets. Indeed, many individual corporate bond issues are

\footnotetext{
${ }^{6}$ Valuing equities based upon exchange-determined closing prices can also be problematic since such prices for many thinly-traded stocks may be stale. See the fair value discussion below.
} 
held mainly as long-term investments in insurance company portfolios and trade very rarely after an initial distribution period. So it is quite possible that a mutual fund may need to produce daily NAV valuations for some specific issues that have not traded for days or even weeks.

We generated our data by merging a comprehensive Morningstar dataset comprising bond holdings for 2,268 U.S. fixed income mutual funds from January 1995 to December 2006 with the Mergent Fixed Income Securities Database containing individual bond characteristics such as issue size, credit rating, and maturity. We supplemented this dataset with data from the TRACE and CRSP Survivor-Bias Free US Mutual Fund databases. All four databases are free of survivorship bias. Our merged holdings dataset enables us to identify the price marks reported by all funds holding the same bond at the same time.

We first examine the cross-fund pricing dispersion of individual bonds. Marking corporate bonds $i s$ hard. Prior to the introduction of TRACE, the interquartile range for the month-end marks of a typical high-yield bond was about 88 cents (per $\$ 100$ of par value). The results show, as expected, that pricing dispersion is related to bond-specific characteristics typically associated with market liquidity. Specifically, cross-fund pricing dispersion is lower for higher credit quality bonds; higher for longer maturity bonds; and lower for larger-sized issues. Our results also show, as expected, that pricing dispersion for individual bonds increases during periods when interest rate volatility is high.

Our key tests at the individual bond level regarding TRACE examine how the improved flow of trade reports via TRACE affected the precision of mutual fund bond pricing. As we later explain, FINRA phased in TRACE over a 27-month period extending from July 1, 2002 to September 30, 2004. The implementation timetable differed for bonds in four groups categorized by credit rating and issue size. Bonds in all four groups experienced economically and statistically significant decreases in cross-fund pricing dispersion after full implementation of TRACE for their group. For a representative bond in the group comprising investment grade bonds with an original issue size greater than $\$ 1$ billion, the cross-fund interquartile range of pricing marks 
dropped from 31.9 cents pre-TRACE to 17.3 cents post-TRACE. ${ }^{7}$ For a representative bond rated $\mathrm{A}$ or higher and issue size between $\$ 100$ million and $\$ 1$ billion, the drop was from 45.9 to 21.8 cents. For a representative bond rated BBB- to $\mathrm{BBB}+$ and issue size less than $\$ 1$ billion, the drop was from 59.8 to 22.5 cents. Finally, for a representative high-yield bond, the drop was from 87.8 to 42.1 cents. Overall, at the individual bond level, our results show that regardless of credit rating or issue size, pricing marks across funds became much more precise once TRACE was implemented.

The period over which TRACE was rolled out included a period when some bonds were included in TRACE while other bonds with similar characteristics were not, creating a natural experimental setting for our research questions. Consistent with the pattern above, bonds in TRACE experienced significant decreases in pricing dispersion across funds. Interestingly, bonds not in TRACE but having similar characteristics experienced significant decreases in pricing dispersion as well, although of a somewhat smaller magnitude. This spillover implies that the TRACE reports on trades in eligible bonds directly helped the market more precisely estimate the current values of related non-reporting bonds. This result is perfectly reasonable given the "matrix pricing" approach typically used by bond market professionals to value an illiquid bond on the basis of any observed prices of other securities with similar coupons, ratings, and maturities. Furthermore, this result mirrors Bessembinder, Maxwell and Venkataraman's (2006) finding that a spillover liquidity effect from the introduction of TRACE resulted in a trade execution cost reduction even for non-eligible bonds.

Additional empirical tests investigate the tendency for funds to systematically mark a disproportionate number of individual bond positions in the same direction relative to the median (consensus) price. We interpret the results as reflecting differences among funds in the use of mid-market prices versus bid-side prices as the position marking standard. Even after controlling for differences in fund marking standards, we continue to find that TRACE increased the precision of mutual fund bond pricing. In regard to bid versus mid marking standards for NAV purposes, we also show that the

\footnotetext{
${ }^{7}$ Bond prices are quoted as a percentage of face (par) value. We interpret all of our individual bond price data in terms of a $\$ 100$ face value. Thus, a reported price of 101.50 represents $\$ 101.50$. Actually, traders would quote this price in the market as 101-16 since the "cents" component is communicated in practice in units of 1/32nds of one percent of par value (the 16 in the 101-16 example quote here refers to 16/32 or $.50)$.
} 
choice has economically significant welfare implications for existing, new and redeeming investors. The welfare implications are particularly significant when a fund experiences large net inflows or outflows and holds relatively illiquid bonds. This would be true, for instance, of a small but rapidly growing high-yield corporate bond fund. Intuitively, the selling of fund shares to new investors at an NAV calculated using bid prices (below mid-market prices) dilutes existing investors' claim on the stream of future income generated by the bond portfolio.

Finally, we investigate whether funds strategically mark bonds to smooth reported returns. Among the majority of funds that mark bonds consistently at bid or mid prices, return smoothing does not appear to be prevalent. However, among the minority of funds that exhibit volatile marking patterns, we find evidence consistent with return smoothing. Our findings are of importance to bond mutual fund investors. Return smoothing involves marking positions such that the NAV is set above or below the true value of fund shares, resulting in wealth transfers across existing, new and redeeming fund investors. Moreover, return smoothing distorts a fund's risk-return profile, such as its Sharpe ratio, perhaps leading investors to make sub-optimal allocation decisions. Our findings also contribute to the literature on return smoothing by delegated portfolio managers. To date, researchers have focused on return smoothing behavior by hedge funds. ${ }^{8}$ Without direct knowledge of hedge fund holdings, researchers have no choice but to use hedge funds' reported returns and rely heavily on econometric techniques to make indirect inferences about the return smoothing behavior of hedge funds. In contrast, we directly estimate the true economic return of bond mutual funds' underlying assets and thus construct more direct tests of return smoothing behavior.

The remainder of the paper is organized as follows. Section I provides a review of the related literature. Section II discusses some specific issues related to valuing the individual holdings of bond funds. Section III discusses our data and summary statistics on bond fund holdings. Section IV presents our main empirical findings on cross-fund individual bond price dispersion, fund-by-fund portfolio marking practices and the impact of TRACE on bond valuation. Section V discusses the impact of bid-price versus

\footnotetext{
${ }^{8}$ See Asness, Krail and Liew (2001), Getmansky, Lo and Makarov (2004) and Bollen and Pool (2006, 2007).
} 
mid-price bond marking standards. Section VI investigates the relationship between marking patterns of certain funds and possible return smoothing behavior. Section VII concludes.

\section{Related literature}

Our research touches on themes that have stimulated a number of recent studies in the academic literature including mutual fund valuation fairness, the relationship between market transparency and pricing efficiency, and the specific impacts of TRACE on the US corporate bond market. A key element of concern in the existing literature is the fairness of current valuations of mutual fund holdings. Two factors undermine the fairness of the values place on a mutual fund's holdings: illiquidity of the securities held and manager discretion over the individual security price marks. Illiquid securities may be hard to value reliably and may lead to stale fund NAV pricing. For example, the last observed trade in an illiquid security may have occurred very early in the trading day (or even on some previous day). Stale prices introduce short-run predictability into a fund's returns. A fund that uses last-trade prices to proxy for true end-of-day values on each of its holdings leaves itself open to market-timing strategies aimed at exploiting stale fund net asset values. Market-timing traders can exploit such short-run predictability to expropriate wealth from the fund's long-term buy-and-hold investors. In addition, an investment manager may use discretion over individual security marks in order to manage returns, i.e., alter reported returns to artificially enhance fund performance. This latter issue goes directly to the heart of the integrity of fund net asset values and fund returns data and becomes entwined with issues regarding fund manager incentives. Thus, the most basic questions regard the reliability and fairness of the marks on individual bond positions set by mutual funds for net asset value (NAV) calculation purposes.

Problems associated with fairly setting daily mutual fund NAVs have been addressed in the academic literature, especially with regard to the activities of markettiming traders. As in Chalmers, Edelen and Kadlec (2001), most of the investigations focus on the impact of nonsynchronous trading effects on fund return predictability. Equity mutual funds traditionally have used exchange posted last-trade closing prices to calculate end-of-day NAVs even if the corresponding last trades occurred much earlier in 
the given trading day. In cases where markets move late in the day, funds using such stale last-trade prices to calculate end-of-day NAVs become targets for strategic markettimers. This phenomenon has been shown to be particularly severe for funds that naturally hold illiquid securities as part of their style - e.g., international equity funds, small-capitalization equity funds and high-yield corporate bond funds. Bhargava, Bose and Dubofsky (1998), Boudoukh, Richardson, Subrahmanyam and Whitelaw (2002), Chalmers, Edelen and Kadlec (2001), Goetzmann, Ivkovic and Rouwenhorst (2001), Green and Hodges (2002) and Zitzewitz (2003) find evidence of large fund trading flows and large excess returns to stale price-oriented mutual fund trading strategies. This research has documented impacts across a large sample of domestic equity, foreign equity and bond mutual funds. These results have focused attention on the need to accurately value securities positions for mutual fund NAV calculations. Our focus on the cross-fund dispersion of mutual fund valuations on a given security offers direct observations and insights into NAV calculation problems at the individual security level.

The literature has also investigated the relationship between market transparency and pricing efficiency and, as relates to corporate bonds, the specific impacts of TRACE on trading costs in the US corporate bond market. This literature distinguishes between pre-trade transparency (e.g., dissemination of bid and ask quotations, market depth, etc.) and post-trade transparency (e.g., timely public reporting of price and quantity data from actual trades). Greater transparency in the trading process may enhance market performance by reducing the opportunities for professionals to exploit their informational advantages over less informed or nonprofessional participants (Pagano and Roell (1996)). Greater transparency may also facilitate improved deterrence and detection of fraud and manipulation (Edwards, Harris and Piwowar (2007)). However, trade disclosure could also impede the amount of liquidity made available by dealers to large traders since disclosure might make it harder for a dealer to unwind large newly-acquired positions profitably (Biaisa, Glosten and Spatt (2005)). ${ }^{9}$ Nevertheless, greater transparency is generally associated with more informative prices (Madhavan (2000)). Indeed, Bloomfield and O'Hara (1999) assess the impact of trade disclosure on market efficiency

\footnotetext{
${ }^{9}$ For a counter-argument, see Naik, Neuberger and Viswanathan (1999). Gemmil's (1996) London Stock Exchange evidence suggests that delays in trade reporting do not increase market liquidity.
} 
in an experimental setting and find that trade disclosure increases the informational efficiency of transactions prices.

In this light, the impact of TRACE's introduction of post-trade price transparency in the secondary corporate bond market is of particular interest. Indeed, TRACE has already attracted attention in the market microstructure transactions costs literature. Bessembinder, Maxwell and Venkataraman (2006) test a simple model of the impact of transaction reporting on transactions costs. They estimate that TRACE eligibility reduces trade execution costs by one-half, and that a spillover liquidity effect results in a one-fifth cost reduction even for non-eligible bonds. ${ }^{10}$ Edwards, Harris and Piwowar (2007) estimate average corporate bond transaction costs as a function of trade size. They show that costs are lower for bonds with transparent trade prices and that such costs drop when TRACE starts to publicly disseminate bond prices. Goldstein, Hotchkiss and Sirri (2007) investigate the last-sale trade reporting impact on BBB-rated corporate bond market liquidity. They find that the effect of post-trade transparency varies with trade size and has a neutral or positive effect on market liquidity. Except for the case of the most infrequently traded issues, bid-ask spreads on bonds whose prices become transparent decline by more than that of a control group.

Bessembinder, Maxwell and Venkataraman's (2006) framework relates directly to our study. They analyze the relationship between market transparency and price efficiency in the context of a world in which transactions costs increase with the variance of valuation errors. ${ }^{11}$ They then motivate a presumed salutary impact of the introduction of TRACE on transactions costs by focusing on the role of improved precision in estimating corporate bond value. Here, we directly study shifts in bond valuation precision associated with the rollout of TRACE via our analysis of cross-fund dispersion of mutual fund valuations. This offers a lens through which to directly view the impact of TRACE on bond valuation precision. Moreover, in contrast to previous studies, our data span the entire time period of the four-phase roll-out of the TRACE system. We test

\footnotetext{
${ }^{10}$ This finding is consistent with a related liquidity externality found for Tel Aviv Stock Exchange securities by Amihud, Mendelson and Lauterbach (1997) since improved price discovery for one security improves price discovery for other related securities.

${ }^{11}$ Bessembinder, Maxwell and Venkataraman (2006) offer two channels for such a relationship: greater valuation errors (1) may increase the inventory risks of market-making and (2) may increase the likelihood that dealers can extract rents from less-well-informed counterparties.
} 
for the marginal impacts that increased post-trade price transparency has had on the precision of individual corporate bond value assessment. In particular, we track whether increased post-trade transparency during the TRACE roll-out led to more precise value assessment as indicated by associated decreases in the cross-fund dispersion of mutual fund marks on individual bonds.

\section{Pricing bond holdings for mutual fund NAV purposes}

A fund's net asset value sets the day's terms at which fund shares may be purchased and redeemed. A mutual fund should ensure that its daily NAV is fairly valued. If a fund's NAV is overstated, redeeming shareholders will receive a windfall that comes at the expense both of other shareholders who remain in the fund and new purchasing shareholders who pay too much for the shares. Likewise, if a fund's NAV is understated, redeeming shareholders will lose out both relative to other shareholders who remain in the fund and new purchasing shareholders who pay too little to acquire their shares. Thus, proper pricing of fund portfolio securities is necessary to ensure fairness among all fund shareholders. As previously discussed, trading strategies exploiting return predictability due to biases in NAVs have generated large excess returns.

Under the Investment Company Act of 1940, the definition of "value" is construed in one of two ways. Securities for which "readily available" market quotations exist must be valued at market value. All other securities must be priced at "fair value" as determined in good faith according to processes approved by the fund's board of directors. Marking a particular security at a fair value requires a determination of what an arm's-length buyer, under the circumstances, would currently pay for that security.

\section{A. Marking positions using readily available market quotations}

As stated in an April 2001 SEC Division of Investment Management letter to the Investment Company Institute, "funds must exercise reasonable diligence to obtain market quotations for their portfolio securities before they may properly conclude that market quotations are not readily available. If, for example, a fund obtains market quotations for a portfolio security from one source and determines that they are unreliable, the fund should diligently seek to obtain market quotations from other 
sources, such as other dealers or other pricing services, before concluding that market quotations are not readily available." 12 Thus, funds are not permitted to ignore these readily available quotations and mark a given position at an internally-generated fair value price. However, for example, a foreign equity fund using stale last-trade closing prices to mark positions is responsible for monitoring for significant events (including general market volatility) that would cause local closing prices to not be considered reliable readily available market prices (Zitzewitz, 2003).

Bond dealer firms and securities pricing services compile daily marks on individual issues. Dealers compile these marks for internal profit and loss determination, repurchase agreement transaction collateral valuation, bond index construction and client servicing purposes. Within each dealer firm, the marks on a given security are generally set by the trading desk responsible for dealing in that security. Traders use available quotes from inter-dealer broker screens on the subject security or related securities, their own customer flows and any available "market color" - stories behind the day's transactions relayed from a variety of sources - as inputs to the marking process. Furthermore, compliance and risk management professionals within the dealer firm typically review the appropriateness of these marks, especially with regard to the integrity of internal daily profit and loss figures. ${ }^{13}$ Dealers provide a great deal of information concerning prices, relative value and insights to institutional buy-side customers. Generally, there is effective best-in-class price knowledge for buy-side customers that have multiple (e.g., five) dealer relationships and access to price quotes from dealer sources. ${ }^{14}$

Securities pricing services produce and offer marks derived from analysis of various sources. Pricing services are for-profit firms that provide prices and pricingrelated data to financial institutions like mutual funds for a fee. Pricing services compete for business along dimensions of pricing quality, security coverage and data transmission reliability. ${ }^{15}$ These data cover both listed market price data for exchange-traded

\footnotetext{
12 http://www.sec.gov/divisions/investment/guidance/tyle043001.htm

13 See Pulliam (2007).

${ }^{14}$ See "An analysis and description of pricing and information sources in the securitized and structured finance markets," The Bond Market Association and The American Securitization Forum, October 2006.

${ }^{15}$ Two of the more important pricing services for evaluated pricing are FT Interactive Data and Standard \& Poor's Security Evaluation Services. Others are Reuters Enterprise Information, Bear Stearns PricingDirect
} 
securities and "evaluated" price data for over-the-counter market securities. The price data for the exchange-listed securities are collected from the exchanges. An "evaluated" price for an over-the-counter market security is produced from firm-specific methodologies that combine information from a number of sources as well as professional judgment. A price needs to be produced each day even if the security in question did not trade that same day. Over-the-counter debt market securities such as US Treasury securities are easy to price. The US Treasury market has transparent, liquid markets for a set of benchmark on-the-run issues. The easily observable quotes on these benchmark issues can be used to value other less liquid, off-the-run issues via standard techniques. However, other over-the-counter debt market securities such as high-yield corporate bonds and distressed debt are more difficult to value. The precision by which such securities can be mechanically marked off of liquid securities like Treasuries or liquid derivatives like Libor-based interest rate swaps is low. Instead, such securities need to be "hand-priced" using an information set that may include actual transaction prices reported during the day by TRACE, indicative bids or offers obtained from bond dealers, and concurrent prices of related securities or derivative contracts.

Thus, as a practical matter, a mutual fund could comply with the Investment Company Act's mandate to mark bond positions using "readily available" market quotations by relying on a single pricing service or multiple securities pricing services and/or securities dealers for the fund's holdings. The fund could adhere to mechanical rules to use a predetermined single source or combine information from a number of sources, or else sometimes utilize discretion in adjustments to the individual security marks. Some funds outsource the actual fund accounting function to firms specializing in that function, while other funds, especially those organized within a large family of funds, perform the fund accounting function in-house.

and Telekurs Financial. Some providers like derivatives specialist Markit Group and Canadian debt specialists SVC Corp. and FRI Corp. focus on specific asset classes. See the March 23, 2007 industry overview article published in Advanced Trading:

http://www.advancedtrading.com/showArticle.jhtml;jsessionid=T0ABWVMTEFC1YQSNDLRCKH0CJU NN2JVN?articleID $=198500315$. For a listing of industry pricing sources relevant for securitized and structured financial products, see "An analysis and description of pricing and information sources in the securitized and structured finance markets," The Bond Market Association and The American Securitization Forum, 2006. 


\section{B. Marking positions using fair value}

Even an exchange-listed security's price may sometimes be supplanted by an evaluated price. Such a listed security's evaluated price is also called a "fair value" price. The intent of fair value pricing is to protect long-term fund investors from strategic shortterm investors who seek to take advantage of funds as a result of significant events occurring after the underlying securities last trade, but before the fund's NAV calculation. SEC Accounting Series Release Nos. 113 and 118 recognize that no single standard exists for determining fair value. By the SEC's interpretation, a board acts in good faith when its fair value determination is the result of a sincere and honest assessment of the amount that the fund might reasonably expect to receive for a security upon its current sale, based upon all of the appropriate factors that are available to the fund. Fund directors must "satisfy themselves that all appropriate factors relevant to the value of securities for which market quotations are not readily available have been considered and to determine the method of arriving at the fair value of each such security." ${ }^{16}$ Interestingly, under the SEC's interpretation, different fund boards, or funds in the same complex with different boards, could reasonably arrive at prices that were not the same when fair value pricing identical securities.

As it happens, the over-the-counter dealer market arrangement of bond markets and general reliance on dealer and/or pricing service marks for individual securities make bond funds generally less susceptible to stale pricing problems that are related to overall market volatility. In particular, bond dealers and bond pricing services will mark individual securities by "matrix pricing" on an option-adjusted yield spread ("OAS") basis against the heavily-traded US Treasury benchmark issues. In this manner, the entire set of bond universe marks will reflect the latest available general market moves through Treasury benchmarks. But because so many corporate bond issues are illiquid and infrequently traded, there tends to be substantial variation in valuations nonetheless. For example, different dealers will experience different customer flows and therefore

\footnotetext{
${ }^{16}$ Subsequent SEC guidance has outlined four obligations for mutual funds relating to fair valuation: (1) adopt written policies and procedures that require the fund to monitor for circumstances that may necessitate the use of fair value pricing; (2) establish criteria for determining when market quotations are not reliable for a particular security; (3) establish methodologies to determine the current fair value of a security; and (4) regularly review the appropriateness and accuracy of the security valuation methods. See "An introduction to fair valuation," Investment Company Institute, ICI Mutual Insurance Company and the Independent Directors Council, 2005.
} 
may form different opinions about the underlying value of any infrequently traded issue. The information a bond dealer collects through seeing specific customer trading flow goes beyond the trade's price. The size of the trade, the identity of the customer, and any explanations from the customer about the reasons behind the trade all matter. Thus, a dealer who has not traded a particular illiquid bond for an extended period will have a less informative opinion on its current value than one who has recently traded it. Zitzewitz (2003) finds some evidence of NAV predictability in high-yield bond funds. Such evidence is at least partially consistent with the view that some price staleness may still be a problem for bond funds. Nevertheless, grossly inefficient extrapolative valuation rules should not survive competitive pressures within the pricing services industry. Indeed, such pricing services should seek to distinguish themselves by doing a good job of hand-pricing infrequently traded "hard-to-mark" securities. Thus, given the incentives in place, we would expect that pricing services would generate unbiased valuations of even the hardest-to-mark securities.

Variation among the valuations used by different mutual funds for the same corporate bond can be attributed to a number of factors. Some of these factors relate to the underlying valuation analytics. Important differences may exist in the specific inputs and models used by price providers to develop the pricing matrix applicable to the individual corporate bonds. Price services seek to differentiate themselves in the eyes of subscribing funds through offering "best-in-class" methodologies. But other factors driving variation in bond valuations will relate to choices made by the funds themselves. Specifically, pricing services may provide a menu of marking alternatives that permit any subscribing fund to choose either 3:00 PM or 4:00 PM benchmark Treasury yield curves as the "closing" benchmark curve. Furthermore, some pricing services offer funds the choice of marking the positions either at "bid" prices or at "mid" prices. ${ }^{17}$ We will provide some insights into the theoretical and empirical importance of this "bid" versus "mid" choice in later sections of this paper.

\section{Data and mutual fund corporate bond ownership statistics}

\footnotetext{
17 The pricing service would develop an estimate of the "bid-ask" spread for each bond and then subtract half of this spread from the bond's mid price to produce a "bid" price.
} 


\section{A. Data}

We use four databases in our study: (1) the Morningstar mutual fund holdings database, (2) the CRSP Survivor-Bias Free US Mutual Fund Database, (3) the Mergent Fixed Income Securities Database (FISD), and (4) the TRACE (Trade Reporting and Compliance Engine) database, which reports over-the-counter (OTC) corporate bond trades.

From Morningstar, we obtained mutual fund holdings data from January 1995 to December 2006 for 2,268 funds classified as fixed income funds. For each fund and date, the Morningstar mutual fund holdings database reports the CUSIP identifier of each security held and both the market and face values of each particular security holding. Based on the available Morningstar investment categories, each fund falls into one of four broad groups: Corporate Bond Funds, Government Bond Funds, Municipal Bond Funds, and Foreign Bond Funds. The database includes both surviving and dead funds and reports many additional statistics for each period in which a fund had a holdings report. Some of these fund statistics include an average maturity score, average credit quality, average duration, and several additional portfolio composition variables such as percentage invested in: government bonds, corporate bonds, bonds of a particular credit rating (e.g., AAA or BBB), etc. Although funds were mandated to publicly report holdings only semiannually until 2004 and quarterly thereafter, some funds voluntarily reported holdings to Morningstar monthly.

From the CRSP Survivor-Bias Free Mutual Fund Database, we obtained monthly mutual fund returns. The Morningstar and CRSP databases were merged using algorithms based on matching fund tickers and fund names. Over the 2003-2006 period when both databases reported bond holdings, our matching algorithm was supplemented with matches for holding positions. Out of the 2,268 funds in Morningstar we were able to find a match for 2,123 funds from the CRSP Database. ${ }^{18}$

From FISD, we obtain the credit rating, coupon rate, maturity date and issue size for a given bond at a particular point in time. We merged FISD with Morningstar holdings using bond CUSIPs.

\footnotetext{
${ }^{18} \mathrm{CRSP}$ mutual fund return data is reported at the fund share class level and not at the portfolio level. We computed a single portfolio return each month by averaging the returns of all share classes belonging to a common portfolio after weighting the returns of each share class by the assets of each share class.
} 
Finally, from the TRACE database, we identified for each bond the time interval over which trade reports appeared in the database. We merged the TRACE data with the rest of the data using bond CUSIPs. As we later describe, to identify TRACE-eligible bonds during the transition period, we check whether each bond each month appeared in the TRACE database. During the transition phase, we presume that a bond was TRACE eligible over the period extending from the first to last appearance of a trade report in the TRACE database.

\section{B. Mutual fund ownership profiles of corporate bonds}

We use two measures to quantify and assess bond mutual fund ownership characteristics for different types of bonds. This first measure, Own Ratio, is calculated for each bond in a given year as the percentage of the issue size held by all 2,268 bond mutual funds. The second measure, Own Number, is calculated for each bond in a given year as the number of funds holding that bond. As in Falkenstein (1996), both of these measures are calculated every year and use the latest holdings report in a given year for a given mutual fund. The average and median values reported in Table I are taken across year-bond observations. There are 71,758 year-bond observations corresponding to a set of 15,291 non-convertible corporate bond securities categorized as such by FISD.

\section{$<$ Insert Table I about here>}

Panel A of Table I reports ownership statistics for all bonds. Panel B reports mean and median values for the ownership statistics by credit rating group. Each credit rating group suppresses the half-step distinctions (e.g., AAA-, AAA, and AAA+ bonds are all categorized as AAA). Panel $\mathrm{C}$ reports statistics categorized by the size of the issue. Each year, bonds are ranked on issue size and placed into deciles where the highest-issue-size bonds are placed in Decile 1 and lowest-issue-size bonds are placed in Decile 10. Ownership statistics categorized into 4 groups defined by the time to maturity are reported in Panel D.

The results in Table I reveal that the ownership impact of bond mutual funds on the corporate bond market tends to be relatively more concentrated in the intermediate 
maturity and high-yield sectors. For example, the median Own Ratio for high-yield bonds is more than four times the corresponding value for investment grade bonds. Perhaps more striking, the median Own Ratio for B-rated bonds is almost ten times the corresponding value for AAA-rated bonds. Across the maturity spectrum, mutual funds own substantially higher fractions of outstanding issues in the intermediate 5-to-10-year sector than they do in other maturity sectors. For example, the median Own Ratio for 5to-10-year issues $(7.67 \%)$ is more than double the corresponding value for the $>10$-year issues $(3.59 \%)$. There does not appear to be any issue size-related tendency regarding mutual fund participation as measured by the Own Ratio. However, the results for Own Number measure clearly reveal that the largest issues are the most widely-held. In the issue-size dimension, the median number of funds holding a top-decile bond is 21 , while the median number of funds holding a bottom-decile bond is just 1. The Own Number results for our sample of mutual funds suggest that large-sized, 5-to-10-year maturity, high-yield bonds are the most widely-held corporate issues.

\section{Cross-fund price dispersion for the overall sample of funds}

\section{A. Measures of bond price dispersion}

For each fixed income fund and each reporting period, the Morningstar mutual fund holdings database reports the market value of each bond holding together with the face value of the position. To calculate the reported price of bond $i$ held by fund $j$ at date $t$, Re ported Price $i, j, t$, we divide the reported market value of that bond holding by the reported face value of the holding and then multiply by 100. In other words, the reported price measure that we use can be interpreted as the price per each 100 dollars of face value. For a bond to be included in our sample, three or more funds must report the price of the identical bond as of the same date. ${ }^{19}$ Our sample includes 11,116 distinct corporate bonds and 252,765 bond-date observations that satisfy this condition.

To measure bond price dispersion across funds, we compute the interquartile range (IR), standard deviation (STD), and average median absolute deviation (MAD) of

\footnotetext{
${ }^{19}$ We also ignored all bond positions that were smaller than $\$ 10,000$ in par value and round the ratio of the reported market value to the reported face value of the holding to the fourth decimal point to avoid spurious differences due to rounding errors.
} 
prices reported by all the funds holding the same bond on the same date. We use the interquartile range and the average median absolute deviation in addition to the standard deviation because the distribution of bond prices across funds is negatively skewed and normality is rejected by the Smirnov-Kolmogorov and Anderson-Darling tests at the 1 percent and 0.5 percent level, respectively. ${ }^{20}$ The resulting dispersion statistics are then averaged across bond-date observations.

\section{B. Univariate sorts}

Table II reports bond price dispersion statistics based on univariate sorts related to bond characteristics. Panel A reports dispersion statistics by credit rating group. As expected, pricing dispersion across funds is generally decreasing in bond credit quality. Panel B reports dispersion statistics by the size of the issue. Bonds are ranked on issue size annually and then placed into deciles. The highest-issue-size bonds are placed in Decile 1 and the lowest-issue-size bonds are placed in Decile 10. Also as expected, dispersion is nearly monotonically decreasing in issue size. Panel $\mathrm{C}$ reports dispersion statistics categorized into four groups defined by the time to maturity. Again as expected, dispersion is increasing in time-to-maturity.

$<$ Insert Table II about here>

\section{Multivariate regressions}

We next relate bond price dispersion to bond characteristics in a multivariate setting via pooled regressions of bond price dispersion measures on two sets of independent variables. The dependent variable in each regression is a dispersion measure alternatively quantified as the interquartile range (IR), standard deviation (STD), and average median absolute deviation (MAD) of prices reported by all the funds holding the same bond on the same date. The first set of independent variables include the following bond characteristics: Issue Size (log of the original face value of a bond issue expressed in millions of dollars); Maturity (log of the remaining time to maturity of the bond

\footnotetext{
${ }^{20}$ The fact the Anderson-Darling test rejects normality at an even lower significance level is consistent with the fact that this test puts more weight on the tails than the Smirnov-Kolmogorov and that the bond price data is negatively skewed.
} 
expressed in years); Rating Code (a discrete variable ranging from 1 for AAA rated bonds to 22 for $\mathrm{D}$ rated bonds). The second set of independent variables include: Volatility, which is the annualized standard deviation of daily percentage price changes for the 10-year Treasury Note Futures during the concurrent observation month; TRACE Transition Dummy, which takes the value one for observations between July 1, 2002 and September 30, 2004 (when TRACE was partially implemented) and zero otherwise; and Full TRACE Dummy, which takes the value one for observations after September 30, 2004 (when TRACE was fully implemented) and zero otherwise.

Table III presents results for the multivariate analysis of bond price dispersion. The computed t-statistics are based on Rogers (1993) standard errors clustered by bond. As for the univariate analysis, results show that pricing dispersion is related to bondspecific characteristics typically associated with market liquidity and value uncertainty. Again, cross-fund pricing dispersion is decreasing in a bond's credit quality, increasing in its time-to-maturity, and decreasing in its issue size. Results also show, as expected, that pricing dispersion for individual bonds increases during periods when interest rate volatility is high. The key results in Table III are the loadings on the TRACE Transition Dummy and the Full TRACE Dummy. The negative and significant loadings are consistent with the improved flow of trade reports via TRACE increasing the precision of mutual fund bond pricing. The decline in dispersion across funds appears economically significant as well. When we restrict the impact relative to the pre-July 1, 2002 period to be the same for all bonds (as the specifications in Table III do), the interquartile range narrowed by 29.5 cents during the TRACE transition period and 36.0 cents once TRACE was fully implemented.

\section{$<$ Insert Table III about here>}

Our next set of multivariate regressions allow for differing TRACE effects for four groups categorized by credit rating and issue size. The groups correspond to bondcharacteristic criteria specified by FINRA in its phased implementation of TRACE over the 27-month period extending from July 1, 2002 to September 30, 2004. The first group of bonds, or Set I bonds, comprises all investment grade bonds greater than $\$ 1$ billion in 
original issue size. Bonds meeting these specifications became permanently TRACEeligible as of July 1, 2002. For Set I bonds, we run the same pooled multivariate regression as in Table III, but with the following changes to the model specification: The Credit Rating and Issue Size variables are excluded given Set I bond's homogeneity along these dimensions, and the Full TRACE Dummy takes a value of one for observations after July 1, 2002 and zero otherwise. The second group of bonds, or Set II bonds, includes all investment grade bonds rated A or higher with original issue size of $\$ 100$ million or higher. Bonds meeting the Set II specifications became permanently TRACE-eligible as of March 1, 2003. For Set II bonds, we modify the regression model specification in the same way, but with the Full TRACE Dummy taking a value of one for observations after March 1, 2003 and zero otherwise. The third group of bonds, Set III comprises all bonds rated $\mathrm{BBB}-$ to $\mathrm{BBB}+$ with an original issue size less than $\$ 1$ billion. On March 31, 2003 FINRA required the reporting of transaction information for 90 bonds meeting these criteria and on April 14, 2003 expanded the list to 120 bonds. All bonds meeting the criteria became permanently TRACE-eligible as of October 1, 2004. While the number of TRACE-eligible bonds meeting the criteria was first constant at 90 bonds and later constant at 120, the composition changed. To identify TRACE-eligible bonds over the transition period, we check whether each bond each month appeared in the TRACE database. During the transition phase, we presume that a bond was TRACE eligible over the period extending from the first to last appearance of a trade report in the TRACE database. For all bond-month observations falling on this TRACE-reporting timeline, we code the TRACE Eligible Dummy equal to one and zero otherwise. For bond-month observations not falling on the TRACE-reporting timeline, we code the TRACE Ineligible Dummy equal to one and zero otherwise. The Full TRACE Dummy takes a value of one after September 30, 2004 and zero otherwise. Finally, the fourth group of bonds, Set IV, includes all high yield bonds. On July 1, 2002 FINRA required the reporting of transaction information for 50 high yield bonds. All high yield bonds became permanently TRACE-eligible as of October 1, 2004. The number of TRACEeligible high yield bonds stayed constant at 50 over the transition period but the composition changed. For high yield bonds, we construct a TRACE Eligible Dummy, 
TRACE Ineligible Dummy, and Full TRACE Dummy in a manner analogous to that described above.

Table IV reveals that bonds in all four groups experienced economically and statistically significant decreases in cross-fund pricing dispersion after full implementation of TRACE for their group. To get a sense of the economic magnitude of the decrease in pricing dispersion, we interact the Maturity and Volatility loadings with their approximate median values of 5 years-to-maturity and 6 percent per year, respectively. For a representative Set I bond (i.e., investment grade bonds with an original issue size greater than $\$ 1$ billion), the cross-fund interquartile range of pricing marks dropped from 31.9 cents before TRACE to 17.3 cents after full implementation of TRACE. For a representative Set II bond (i.e., A or higher rated bonds with an issue size between $\$ 100$ million and $\$ 1$ billion), the drop was from 45.9 to 21.8 cents. For a representative Set III bond (i.e., BBB- to $\mathrm{BBB}+$ rated bonds with an issue size less than $\$ 1$ billion), the drop was from 59.8 to 22.5 cents. Finally, for a representative Set IV bond (i.e., high-yield bonds), the drop was from 87.8 to 42.1 cents. Overall, our results at the individual bond level show that regardless of credit rating or issue size, cross-fund price dispersion decreased after TRACE was implemented.

\section{$<$ Insert Table IV about here>}

As we described above, FINRA's phased approach to the implementation of TRACE included a period when some bonds rated BBB- to BBB+ with issue sizes less than $\$ 1$ billion and high yield bonds were TRACE-eligible while other bonds with similar characteristics were not, creating a natural experimental setting for our research questions. The loading on the TRACE Eligible Dummy in Panel B of Table IV is consistent with TRACE-eligible bonds experiencing significant decreases in pricing dispersion across funds. Interestingly, the loadings on the TRACE Ineligible Dummy are consistent with non-eligible, but otherwise similar, bonds experiencing significant decreases in pricing dispersion as well, although of a somewhat smaller magnitude. This spillover implies that the TRACE reports on trades in eligible bonds directly helped the market more precisely estimate the current values of related non-reporting bonds. This 
result is reasonable given the matrix pricing approach typically used by bond market professionals to value an illiquid bond on the basis of any observed prices of other securities with similar coupons, ratings, and maturities. Furthermore, this result mirrors Bessembinder, Maxwell and Venkataraman's (2006) finding that a spillover liquidity effect from the introduction of TRACE resulted in trade execution cost reductions even for non-eligible bonds.

\title{
V. "Mid" versus "bid" bond pricing
}

\section{A. Institutional details}

SEC Accounting Series Release No. 118 provides guidance on how investment companies should value over-the-counter securities like corporate bonds to be in compliance with the Investment Act of 1940:

\begin{abstract}
"Because of the availability of multiple sources, a company frequently has a greater number of options open to it in valuing securities traded in the over-thecounter market than it does in valuing listed securities. A company may adopt a policy of using a mean of the bid prices, or of the bid and asked prices, or of the prices of a representative selection of broker-dealers quoting on a particular security; or it may use a valuation within the range of bid and asked prices considered best to represent value in the circumstances. Any of these policies is acceptable if consistently applied. Normally, the use of asked prices alone is not acceptable."
\end{abstract}

The SEC's guidance suggests that mutual funds should either be choosing to mark bond values at the bid price or at the mid-market price (i.e., the average of the bid and ask prices). The choice between employing a bid or mid valuation concept is important for markets like high-yield corporate bonds where bid-ask spreads can be relatively wide. Regarding mutual fund accounting issues, FASB 157 on Fair Value Measurements issued in September 2006 also specifies that the price within the bid-ask spread that is most representative in the circumstance should be used to measure fair value.

We checked these pricing guidelines against how mutual funds report their debt securities pricing practices by examining Prospectuses together with the Statements of Additional Information of several bond funds. Consistent with the SEC's guidance, we observed that some funds explicitly described a practice of marking their debt securities 
using bid marks, ${ }^{21}$ whereas some other funds described a practice of marking debt securities using mid marks. ${ }^{22}$ Alternatively, some other funds did not provide much detail about their pricing practice beyond mention of using pricing services as price sources.

\section{B. Categorizing funds by pricing standard}

We investigate the bid and mid pricing practices of our sample funds by exploring the tendency for funds to systematically mark a disproportionate number of individual bond positions in the same direction relative to the consensus (i.e., the cross-sectional sample median) price. If the underlying process driving the dispersion in individual position marks is random, and if all funds mark their bond positions using a common standard (i.e., mid pricing or bid pricing), then the number of positions marked above the consensus price for a particular fund on a particular date should roughly equal the number marked below. We screen for funds that mark a disproportionately large fraction of individual bond positions above consensus prices. We also screen for funds that mark a disproportionately large fraction of individual bond positions below consensus prices. We use this screening process to infer the pricing standard used by the fund to mark bonds for NAV purposes. Intuitively, our process presumes that a fund observed marking the vast majority of its bonds below consensus prices on a given date is marking bonds at bid prices, whereas a fund observed marking the vast majority of its bonds above consensus prices on a given date is marking bonds at mid prices.

We follow a three step process that places each fund in a given sample period into one of six pricing categories: presumed mid marker, presumed bid marker, unclassifiable marker, bid-to-mid switcher, mid-to-bid switcher, or volatile marker. First, for each fund report date, we determine whether the mark of each bond held was above, equal to, or

\footnotetext{
${ }^{21}$ The following is an example of language used in the prospectus of a fund that uses a bid marking pricing standard: "Securities that are not traded primarily on an exchange generally are valued

using latest quoted bid prices obtained by an independent pricing service" (see http://www.sec.gov/Archives/edgar/data/1081400/000119312508071373/0001193125-08-071373.txt).

${ }^{22}$ The following is an example of a fund that uses a mid mark pricing standard: "Securities for which market prices are not provided by any of the above methods may be valued based upon quotes furnished by independent sources and are valued at ...in the case of debt obligations, the mean between the last bid and ask prices" (see http://www.sec.gov/Archives/edgar/data/842790/000095012908002505/0000950129-08$\underline{002505 . t x t)}$.
} 
below the consensus price. Second, each fund date is screened for systematically high marks using a binomial test based on the number of bonds marked above consensus prices relative to the total number of bonds. ${ }^{23}$ To ensure that our inferences are based on sufficient data, our sample only includes dates when funds report holdings for ten or more bonds with valid consensus prices. This restriction produces a sample of 930 funds. ${ }^{24}$ Fund dates are recorded as "up dates" when the majority of individual positions have marks above consensus prices such that the one-sided $p$-value from the binomial test is less than five percent under the null that marking individual positions above or below the consensus price is equally likely. Fund dates are recorded as "down dates" in an analogous fashion. Thus, each date for which a fund reports portfolio holdings is categorized as an "up date," a "down date" or remains an "unclassified date." In the third step, a fund is categorized as a presumed mid marker if no date for that fund can be categorized as a "down date" and the rest of the dates are categorized as a mixture of "up dates" and "unclassified dates." A fund is categorized as a presumed bid marker if no date for that fund can be categorized as an "up date" and the rest of the dates are categorized as a mixture of "down dates" and "unclassified dates." A fund is categorized as an unclassifiable marker if all its portfolio dates are "unclassified dates." A fund is categorized as a bid-to-mid switcher if the classification of its portfolio dates changed once from "down dates" to "up dates." A fund is categorized as a mid-to-bid switcher in a similar way. Finally, a volatile marker is a fund that experienced multiple changes in the classification of its portfolio holdings report dates from "down dates" to "up dates" to "down dates" again, or vice versa. As a robustness check, we repeat the above classification process using only the fund's 20 bonds with the lowest expected price dispersion. $^{25}$

\footnotetext{
${ }^{23}$ We include position marks equal to the consensus price in the total number of bonds to reduce the probability of making Type I errors for up and down date calculations.

${ }^{24}$ Although the restricted sample of 930 funds includes some funds not explicitly classified as corporate bond funds such as government bond funds with substantial investments in corporate bonds, $92 \%$ of the funds are corporate bond funds.

${ }^{25}$ This is an attempt to increase the signal to noise ratio of our categorization algorithm. Expected price dispersion for a given bond is calculated from a pooled regression where the dependent variable is bond price dispersion measured as the interquartile range (IR) of prices reported by all funds holding the same bond on the same date and the independent variables are: Issue Size ( $\log$ of the original face value of a bond issue expressed in millions of dollars); Maturity (log of the remaining time to maturity of the bond expressed in years); Rating Code (a discrete variable ranging from 1 for AAA rated bonds to 22 for D rated
} 
Panel A of Table $\mathrm{V}$ reports the frequency of funds in each of the six pricing standard categories for the overall sample period (01/31/1995-12/31/2006), the preTRACE period (01/31/1995-06/30/2002), and the post-TRACE period (10/31/200412/31/2006). In Panel A.1, the categorization algorithm uses all of the bonds held by the fund. In Panel A.2, the categorization algorithm uses only the 20 bonds with the lowest expected price dispersion from among those held by each fund. Panel A.1 shows that presumed mid markers and presumed bid markers together comprised about two-thirds of the overall and pre-TRACE period samples and more than three-quarters in the postTRACE period sample. Specifically, presumed mid markers comprised 27.5\%, 29.0\%, and $34.8 \%$ of the sample in the overall, pre-TRACE, and post-TRACE periods, respectively. ${ }^{26}$ Presumed bid markers comprised slightly higher percentages during these periods at $36.0 \%, 38.1 \%$, and $42.1 \%$, respectively. Interestingly, the third largest category in the overall period was volatile markers at $16.77 \%$. The volatile markers exhibited a pattern consistent with switching their marking standard at least twice. For example, a volatile marker might first have marked a disproportionate number of bonds above consensus prices, then below, and then above again. Or else a volatile marker might first have marked a disproportionate number of bonds below consensus prices, then above, and then below again. Even over the shorter pre-TRACE and post-TRACE subperiods, volatile markers comprised $6.7 \%$ and $5.1 \%$ of the samples, respectively. Panel A.2 shows that results are similar when only bonds with low expected pricing dispersion are used to categorize funds.

$<$ Insert Table $\mathrm{V}$ about here>

Panel B of Table V reports the frequency of funds in each category during the post-TRACE period contingent upon their categorization during the pre-TRACE period. Funds that were no longer in existence post-TRACE or that had insufficient data post-

bonds); and Volatility, which is the annualized standard deviation of daily percentage price changes for the 10 -year Treasury Note Futures.

${ }^{26}$ The frequency of presumed mid markers in the pre-TRACE period is reasonably similar to the estimate reported in the Capital Market Risk Advisors' survey conducted in 2000 and summarized by Rahl (2001). In that survey, 38\% percent of the mutual fund respondents (which included both bond and equity funds) indicated that they used a mid-market pricing standard. 
TRACE are categorized as dead funds. Again Panel B.1 uses all of the fund's bonds to categorize funds and Panel B.2 uses only the fund's 20 bonds with the lowest expected price dispersion. Panel B.1 shows that a majority of presumed mid markers in the preTRACE period continued to be categorized as presumed mid markers in the post-TRACE period. Of the 205 presumed mid markers in the pre-TRACE period, 118 (or 57.6\%) were categorized as presumed mid markers in the post-TRACE period. When the 40 dead funds in the post-TRACE period are excluded, the 118 presumed mid markers in the post-TRACE period represent $71.5 \%$ of the remaining 165 presumed mid markers in the pre-TRACE period. Presumed bid markers exhibit similar stability across the pre- and post-TRACE subperiods. Of the 269 presumed bid markers in the pre-TRACE period, 150 (or 55.8\%) were categorized as presumed bid markers in the post-TRACE period. When the 50 dead funds are excluded, the 150 presumed bid markers in the post-TRACE period represent $68.5 \%$ of the remaining 219 presumed bid markers in the pre-TRACE period. We also observe evidence of stable marking behavior in that bid-to-mid switchers in the pre-TRACE period exhibit a tendency to be presumed mid markers in the post-TRACE period and mid-to-bid switchers in the pre-TRACE period exhibit a tendency to be presumed bid markers in the post-TRACE period. Again, Panel B.2 shows that results are similar when categorizing funds using only bonds with the lowest expected pricing dispersion.

\section{Pricing dispersion controlling for mid and bid pricing}

Up to now, our pricing dispersion estimates have been based upon bond prices reported by all funds without regard to the underlying marking standard employed. Since some funds mark bonds using mid prices and others mark bonds using bid prices, our dispersion measures are affected by the magnitude of the bid-ask spread. In fact, it is possible that the decreased pricing dispersion we find in Tables III and IV across all funds may simply be due to the post-TRACE decrease in bond spreads documented by Bessembinder, Maxwell and Venkataraman (2006), Edwards, Harris and Piwowar (2007), and Goldstein, Hotchkiss and Sirri (2007). To investigate this possibility, we repeat the earlier analysis after first controlling for the marking standard used by each fund. That is, we run new separate analyses using only funds that marked bonds in the 
same way over the whole sample period. We first compute dispersion measures using only the funds categorized as presumed mid markers in the overall, pre-TRACE, and post-TRACE periods. We refer to these 115 funds as consistent mid markers. We also compute dispersion measures separately using only the funds categorized as presumed bid markers in the overall, pre-TRACE, and post-TRACE periods. We refer to these 116 funds as consistent bid markers. As with the previous price dispersion calculations, we only consider bond-date observations where the bond was held by at least three funds in the pricing subgroup.

Table VI reports regression results in the style of Table IV after limiting the data to consistent mid markers (Panel A) and consistent bid markers (Panel B). Table VI reveals that for both pricing subgroups, bonds in all four TRACE-implementation sets experienced economically and statistically significant decreases in cross-fund pricing dispersion after full implementation of TRACE. Interestingly, the estimated magnitude of the pricing dispersion decrease is larger for consistent bid markers than consistent mid markers. Clearly, bid prices are dependent upon the width of the bid-ask spread as well as the mid-market price level. Thus, the observed larger pricing dispersion decrease for consistent bid markers makes sense to the extent that TRACE's increased transparency increased the precision of bid-ask spread estimation. In sum, the observed post-TRACE decrease in cross-fund dispersion for the full sample was not entirely attributable to a narrowing of bond bid-ask spreads. Greater post-TRACE trade transparency clearly reduced the dispersion in bond price estimates even after we control for differences in fund marking standards.

\section{$<$ Insert Table VI about here>}

\section{Some remarks on the welfare impacts of choosing mid versus bid pricing}

The choice of bid versus mid pricing affects the NAV at which investors buy and sell shares. Since funds are pooled investment vehicles, the choice thus impacts the price at which investors transact with each other. In this section, we consider the welfare implications of mid versus bid pricing for investors. 
Welfare implications for investors of funds that switch from one pricing standard to another are dependent upon when fund shares are bought and sold. New investors who buy shares at NAVs based on mid prices and redeem shares at NAVs based on bid prices lose one-half of the weighted average bid-ask spread of the bonds held by the fund. Existing investors who continue to hold fund shares capture this lost half-spread. Similarly, new investors who buy shares at bid prices and redeem shares at mid prices gain the half-spread at the expense of the fund's existing investors.

The choice of mid or bid pricing also has welfare implications that are dependent on the net investor flows that occur over the holding period of existing investors. The flow-dependent welfare implications apply to existing investors even if the fund consistently adheres to a single pricing standard for NAV purposes. To illustrate, consider two funds that are identical in all respects except for the way bonds are marked for NAV purposes. The first fund marks bonds at mid prices and values its portfolio at $\$ 1,000,000$. Suppose that the half-spread is 50 basis points. The second fund marks bonds at bid prices and values the identical portfolio at $\$ 995,000$. Assume there are 10,000 existing investors holding equal claims of one share each. Thus, the mid-marking fund sets the NAV at $\$ 100.00$ per share and the bid-marking fund sets the NAV at $\$ 99.50$ per share. Now suppose that the funds experience identical new investor inflows of $\$ 1,000,000$. The mid-marking fund sells 10,000 shares to new investors at $\$ 100.00$ each, leaving existing investors with a claim on future fund distributions of exactly $50.00 \%$ (10,000 of 20,000 total outstanding shares). The bid-marking fund sells 10,050.25 shares to new investors at $\$ 99.50$ each, leaving existing investors with a claim of only $49.87 \%$ $(10,000$ of $20,050.25$ total outstanding shares). If the fund experienced zero new net flows and its bond portfolio generated \$200,000 in distributable income, then existing investors of the mid-marking fund and bid-marking fund receive distributions of $\$ 10.00$ and \$9.9749, respectively. With zero new net flows, existing investors of the bidmarking fund will continue to suffer a greater than 25 basis point reduction in distributions for as long as they hold their shares. Recognize that further net inflows would exacerbate the dilution of existing investors' claim on distributions going forward.

More generally, we can calculate the welfare implications for existing investors as a function of $F$, net investor flows expressed as a percentage of the fund's total net 
assets, and $S$, the half-spread of bonds held by the fund. Existing investors' claim expressed as a percentage of the fund's outstanding shares under bid marking in comparison to mid marking is computed as follows: ${ }^{27}$

$$
\phi_{b i d}=\frac{1}{1+\frac{F}{1-S}}-\frac{1}{1+F}
$$

Equation (1) shows that for net inflows, existing investors receive smaller distributions going forward under bid marking than mid marking (i.e., $\phi_{b i d}<0$ for $F>0$ ). Intuitively, selling fund shares to new investors at an NAV calculated using bid marks below midmarket prices dilutes existing investors claim on the stream of future income generated by the bond portfolio. In contrast, for net outflows, existing investors benefit (i.e., $\phi_{b i d}>0$ for $\left.F<0\right)$. Intuitively, redeeming investors' loss from selling fund shares at a NAV calculated using marks below mid-market prices is transferred to existing investors who continue to hold their fund shares. Comparative static results show, as expected, that the magnitude of the welfare impact in equation (1) is increasing in the magnitude of net flows and the half spread. The welfare implications from marking at bid prices instead of mid-market prices can be economically significant when a fund experiences large net inflows or outflows and holds relatively illiquid bonds. This would be true, for instance, of a small, but rapidly growing, fund that primarily held high yield corporate bonds.

The normative implications are straightforward with respect to the stability of the policies used to mark bonds for NAV purposes. If the equitable treatment of investors who transact at different times is an objective, then clearly funds should adhere to a consistent mid or bid marking standard. Whether the best practice for funds is to mark at

${ }^{27}$ Under bid marking, net flows of $F$ transact at a share price of $\frac{1}{1-S}$, leaving existing investors with a claim equal to $\frac{1}{1+\frac{F}{1-S}}$ percent of the fund's outstanding shares. Under mid marking, net flows of $F$ transact at a share price of 1, leaving existing investors with a claim equal to $\frac{1}{1+F}$ percent of the fund's outstanding shares. Equation (1) is the difference between existing investors' claims under bid and mid marking. 
mid or bid prices depends on one's view of the best estimate of a bond's market value. An argument in favor of mid pricing is that the fund is an ongoing concern; hence, it will not be forced to liquidate bonds at bid prices and mid prices represent the better estimate of bond market values.

\section{A closer look at volatile markers}

SEC Accounting Series Release No. 118's guidance on how investment companies should value over-the-counter securities like corporate bonds to be in compliance with the Investment Act of 1940 gives funds leeway for using bid-price or mid-price marks: "Any of these policies is acceptable if consistently applied." Using the full sample results reported in Table V Panel A.1, the large majority of the funds studied can be construed as following a consistent approach (or switching just once from one approach to another). Nevertheless, we labeled $16.8 \%$ of funds as presumed volatile markers. They exhibited a pattern consistent with switching their marking standard at least twice. Over the shorter pre-TRACE and post-TRACE subperiods, presumed volatile markers comprised $6.7 \%$ and $5.1 \%$ of the samples, respectively. However, none of the funds was a volatile marker in each of our three samples: the overall, pre-TRACE, and post-TRACE. $^{28}$ These results suggest that inconsistent position marking violating the SEC's guidance exists but is not endemic in the fund industry taken as a whole.

Nevertheless, we find it interesting to take a closer look at these volatile markers in the context of returns management (e.g., return smoothing) by funds. This phenomenon involves investment manager use of discretion over marks on individual holdings to alter the distribution of reported fund investment returns. The goal of such returns management would be to artificially enhance a fund's performance statistics. In the mutual fund space, the ultimate goal of such return management schemes would be to attract additional investment inflows. In the hedge fund space, returns management would also have direct impacts on current incentive compensation.

Getmansky, Lo and Makarov (2004) suggest that the significant fund return serial correlation documented in their study of hedge funds is driven mainly by problems in valuing the illiquid underlying assets favored within certain hedge fund investment styles,

\footnotetext{
${ }^{28}$ The count is just 1 fund if we use only the 20 bond holdings with the lowest expected pricing dispersion.
} 
although they do not rule out active smoothing of returns by hedge fund managers. Underlying their hypothesis is an assumption that certain assets are hard to mark because of infrequent trading within nontransparent markets. Furthermore, under this view, current fund marks on illiquid assets are generated because fund managers default to extrapolating such marks using stale prices from past trades. Asness, Krail and Liew (2001) had made much the same point in an earlier paper. Indeed, Getmansky et al. estimate smoothing profiles relating reported returns data to (unobserved) concurrent and past true economic returns via a distributed lag model and find higher degrees of smoothing within fund styles that they associate with larger holdings of illiquid assets. As Asness, Krail and Liew (2001) note, "hedge fund managers have a strong incentive to show monthly returns that are both consistent and uncorrelated with the market."29

Empirically distinguishing between the illiquidity and discretionary returns management explanations may be difficult. For one attempt, see Bollen and Pool's (2006) extension of the Getmansky et al. framework to consider conditional serial correlation in an attempt to screen for a particular type of returns management. However, in general, we view both the illiquidity and discretionary returns management ideas as stemming from one common source: manager use of biased marks on individual fund holdings for net asset valuation purposes.

Getmansky et al. test a model of return smoothing for hedge funds which is applicable to any portfolios that hold illiquid assets (such as our bond mutual funds). In the model, fund $j$ 's reported or observable return in month $t$ is denoted $R_{j, t}^{0}$. The fund's true economic return, which is assumed to be unobservable, is denoted $R_{j, t}$. The true economic return reflects the flow of information that would determine the equilibrium value of the fund's securities in a frictionless market. The observable reported returns are modeled as a finite moving average of the unobservable true economic returns. For example, regression equation (2) is a return smoothing model using a specification that allows for three lagged months of true economic returns:

$$
R_{j, t}^{0}=\alpha+\theta_{j, 0} R_{j, t}+\theta_{j, 1} R_{j, t-1}+\theta_{j, 2} R_{j, t-2}+\theta_{j, 3} R_{j, t-3}+\varepsilon_{j, t}
$$

\footnotetext{
${ }^{29}$ Asness, Krail and Liew (2001), page 10.
} 


$$
\text { subject to } 1=\theta_{j, 0}+\theta_{j, 1}+\theta_{j, 2}+\theta_{j, 3} \text {. }
$$

The key coefficient in equation (2) is $\theta_{j, 0}$, which indicates how much of the true economic return is reported in the current month. A $\theta_{j, 0}$ value less than one means that, consistent with smoothed returns, on average fund $j$ reported less than $100 \%$ of the current month's true economic return. A $\theta_{j, 0}$ value equal to one means that on average fund $j$ reported the current month's true economic return. ${ }^{30}$

Our procedure for estimating equation (2) differs from Getmansky et al. in that we estimate (2) directly using a proxy for the true economic returns that we can compute from the fund holdings. Getmansky et al. estimate the model for hedge funds, where the underlying assets are not observable. They fit the model using only reported returns and employ econometric techniques in multiple steps to estimate the $\theta$ coefficients. In contrast, for our sample of bond mutual funds, we can observe the underlying assets held on report dates and use the bond holdings data to derive a proxy for each fund's true economic return. Our proxy for each fund's true economic return is the return that the fund would have experienced had it marked its own individual bond holdings at consensus prices. Our true economic return proxy is independent of a fund manager's specific endogenous decisions about how to mark bonds for NAV purposes. Our exact procedure for calculating the true economic return proxy is described below.

We start by calculating the "portfolio spread" which is measured as the percentage difference between the value of a fund's portfolio of corporate bond positions marked using the fund's own prices and the value of those same positions remarked using consensus bond prices based on prices reported by all funds. We compute portfolio spread as follows. First, for each bond we compute a consensus price. As discussed above, for a bond to be included in our sample, three or more funds must report the price of the identical bond as of the same date. For each bond $i$ meeting this requirement at date $t$, we calculate the consensus price, Consensus Price $_{i, t}$, as the median price reported by all funds. Next, for each fund $j$ at each date $t$, we identify all bonds held with valid

\footnotetext{
${ }^{30} \mathrm{~A} \theta_{j, 0}$ value greater than one would imply that fund $\mathrm{j}$ marked its positions in a way that increased its returns volatility relative to its contemporaneous true economic returns (technically feasible but hard to motivate).
} 
consensus prices (i.e., all bonds held by at least three funds). The consensus value of all such bonds held by fund $j$ at date $t$ is calculated as follows:

$$
\text { Consensus Value }_{j, t}=\sum_{i=1}^{N_{j}} \text { Consensus }_{\text {Price }}{ }_{i, j, t} \times \text { ParValue }_{i, j, t} \text {, }
$$

where ParValue ${ }_{i, j, t}$ is the reported face value of bond $i$ held by fund $j$ at date $t$. In the next step, using the same set of bonds used to calculate Consensus Value ${ }_{j, t}$ we compute the reported value for fund $j$ at date $t$ as follows:

$$
\text { Reported Value }_{j, t}=\sum_{i=1}^{N_{j}} \text { Reported Price }_{i, j, t} \times \text { ParValue }_{i, j, t} .
$$

The reported value reflects the prices used in the fund NAV calculation for bonds with valid consensus prices (i.e., for bonds held by at least two other funds). The portfolio spread, defined as the percentage difference between the reported and consensus values for fund $j$ at date $t$, is calculated as

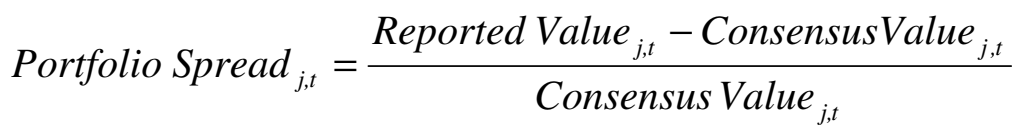

and computed for each fund holding at least ten bonds with valid consensus prices in a given month. We then calculate the percentage change in the portfolio which is due to the change in the portfolio spread as

$$
\Delta \text { Spread }_{j, t}=\frac{\text { Portfolio }_{\text {Spread }}^{j, t}-{\text { Portfolio } \text { Spread }_{j, t-1}}_{\text {Portfolio } \text { Spread }_{j, t-1}}}{.}
$$

Finally, we calculate our proxy for the true underlying portfolio return as 


$$
R_{j, t}=\frac{\left(1+R_{j, t}^{0}\right)}{\left(1+\Delta \text { Spread }_{j, t}\right)}-1
$$

Under our method, $R_{j, t}$ reflects the component of the portfolio return which is not affected by the idiosyncratic marking behavior of the fund manager and is thus a good proxy for the underlying economic return.

We estimate regression equation (2) and compare the return smoothing profiles of consistent markers versus volatile markers. Our estimation period covers the entire sample period and includes only funds with 15 or more valid (non-missing) observations. After applying this minimum-observation filter, 96 consistent markers and 68 volatile markers remain. ${ }^{31}$ Table VII reports results for our estimation of equation (2). In Panel A, observations across funds and periods are pooled together. In Panel A.1, the $\theta_{t}$ coefficients are unconstrained; in Panel A.2, the $\theta_{t}$ coefficients are constrained to sum to one. The third column of results is for the following regression model:

$$
R_{j, t}^{0}=\alpha+\theta_{0} R_{j, t}+\tilde{\theta}_{0} R_{j, t} \times D_{j}+\theta_{1} R_{j, t-1}+\theta_{2} R_{j, t-2}+\theta_{3} R_{j, t-3}+\varepsilon_{j, t}
$$

where $D_{j}$ is a variable that takes a value of one if a fund is classified as a volatile marker and zero if it is classified as a consistent marker. Thus, $\tilde{\theta}_{0}$ is the difference in $\theta_{0}$ coefficient estimates for volatile markers and consistent markers. In the unconstrained estimation, the $\theta_{0}$ coefficient for the volatile markers is 0.8751 , which is significantly less than one in both economic and statistical terms. In contrast, the $\theta_{0}$ coefficient for the consistent markers is 0.9922 and is not significantly different from one in an economically important way. The unconstrained regression's $\tilde{\theta}_{0}$ estimate of -0.1036 is significantly different from zero in both economic and statistical terms, suggesting that the $\theta_{0}$ coefficient for the volatile markers is significantly less than the $\theta_{0}$ coefficient for

\footnotetext{
${ }^{31}$ We also removed some funds classified as non corporate bond funds by Morningstar. These funds were classified as consistent markers (17 funds) or volatile markers (14 funds) because they had substantial holdings in corporate bonds. Including such funds would not change the qualitative nature of any of the following results.
} 
the consistent markers. The implication is that the idiosyncratic part of the typical volatile markers' reported return was in the opposite direction of the contemporaneous true economic return. This is consistent with return smoothing. In contrast, consistent makers reported true economic return in the same month they occurred without an upward or downward amplification. Results are qualitatively similar when the $\theta_{t}$ coefficients are additionally constrained to sum to one (Panel A.2).

\section{$<$ Insert Table VII about here>}

As a robustness check, Panels B and C of Table VII provide results where we estimate equation (2) using two alternative methods. In Panel B, the parameter estimates from equation (2) are estimated, as in Fama-MacBeth, for each month separately and then averaged across months, with reported $t$-statistics based on the time series standard errors, which have been further corrected to account for serial correlation using the Newey-West correction. $^{32}$ Only months with 15 or more valid observations are included in the monthly regressions. ${ }^{33}$ In Panel C parameter estimates from equation (2) are estimated separately for each fund and then averaged across funds. Panel $\mathrm{C}$ reports the averaged parameter values along with $t$-statistics based on the cross-sectional standard errors ${ }^{34}$ and, as in Panel A, only funds with 15 or more valid (non-missing) observations are included. The third column of results in Panels B and C show the difference between the estimated $\theta_{0}$ coefficients for volatile markers and consistent markers. The associated $t$-statistics based on a $t$-test of the null that the mean $\theta_{0}$ coefficients are equal for the volatile markers and consistent markers. Again, regardless of the method used to estimate the return smoothing model, the $\theta_{0}$ coefficient for the volatile markers is significantly less than one in both economic and statistical terms. This finding is consistent with smoothed returns. In contrast, regardless of the estimation method, the $\theta_{0}$ coefficient for the consistent markers does not differ from one in an economically meaningful way, consistent with the contemporaneous reporting of true economic return without an

\footnotetext{
${ }^{32}$ We followed the automatic lag selection procedure of Newey and West (1994).

${ }^{33}$ Results are qualitatively similar when this restriction is relaxed.

${ }^{34}$ This approach is best suited to control for serial-correlations both in the independent variables and residuals (see Petersen (2008)).
} 
upward or downward amplification. Furthermore, regardless of the method used to estimate the return smoothing model, the coefficient for the volatile markers is significantly less than the coefficient for the consistent markers in a statistical sense.

The observed differences in the estimated $\theta_{0}$ parameters could be due to differences in the illiquidity of the underlying assets for the volatile and consistent markers, whereby volatile markers perhaps hold less liquid bonds that are harder to value. In this regard, we explored whether there were any systematic portfolio differences between the volatile and consistent markers. In Table VIII we report fund characteristics separately for the volatile and consistent markers. We first average fund characteristics across all observations belonging to a particular fund and then compute a set of statistics based on the cross-sectional distribution. Credit rating, issue size, and maturity are calculated as the weighted average of the bond characteristics comprising each portfolio each date, with weights equal to the market value of each bond position as reported by the fund. \% Non-Inv. Grade represents the weight of a fund portfolio in non-investment grade bonds. Bond Issue Size, Fund Family Assets, and Fund Assets are reported in millions. Results from Table VIII do not reveal any major differences between the two groups, with the notable exception that, contrary to our conjecture, the volatile markers seem to hold slightly higher credit quality bonds and smaller fraction of non-investment grade bonds.

\section{$<$ Insert Table VIII about here>}

Taken all together, these results suggest that return smoothing behavior can be associated with our sample of volatile markers. However, we emphasize that volatile markers make up a small proportion of the entire universe of bond mutual funds. Perhaps the more interesting findings are that the marks used by our consistent markers do not appear to be associated with return smoothing. These findings are all the more striking because, for the most part, the corporate bonds under study here are illiquid, thinly-traded securities. Recall that Getmansky et al. suggest that their own significant fund return serial correlation results are driven mainly by problems in valuing the illiquid underlying assets favored within certain hedge fund investment styles. As we have argued 
previously, grossly inefficient extrapolative valuation rules should not survive competitive pressures within the pricing services industry. Widespread use of professional pricing services by bond mutual funds to value corporate bond holdings appears to have resulted in marks that do not suffer from grossly inefficient extrapolative valuation biases. Given the Getmansky et al. results, an evaluation of the security valuation practices of individual hedge funds with regard to the use of independent professional asset pricing services might be a worthwhile endeavor for both the hedge fund industry and its would-be regulators.

\section{Conclusions}

This paper has analyzed important aspects of US corporate bond pricing by mutual funds and related issues in bond market structure and transparency. Our analysis focused on the dispersion of month-end valuations placed on identical bonds by different funds for net asset value purposes. Fundamentally, our mutual fund bond valuation data allowed us to assess the difficulty of marking illiquid securities. Our results indicate that cross-fund bond price dispersion falls as bond credit quality increases, rises for longer bond time-to-maturity, and falls for larger bond issue size. Price dispersion for individual bonds also tends to be higher when underlying market volatility is high.

Corporate bond market transparency improved dramatically with the establishment of FINRA's TRACE system in July 2002. While previous research has focused on the salutary impacts of TRACE on bond trade execution costs, the improvement in market transparency has more general benefits. We developed specific tests of the impact of the TRACE's rollout on the precision of bond valuation by mutual funds. We found that the trade transparency generated by TRACE has increased the precision of bond pricing for NAV purposes to the benefit of mutual fund investors. Furthermore, we uncovered and analyzed some systematic differences in bond holdings valuations that appear to incorporate the impact of differences in fund bid versus mid bond value marking standards. Greater post-TRACE trade transparency clearly reduced the dispersion in bond price estimates even after we controlled for differences in fund marking standards. Finally, we find the volatile marking patterns of some funds to be 
associated with return smoothing behavior. However, return smoothing behavior does not appear to be prevalent across our sample of bond mutual funds. 


\section{Table I \\ Corporate Bond Ownership Statistics}

The following table reports ownership statistics for bonds that are held by 2,268 bond mutual funds that reported their holdings to Morningstar during the 1995-2006 period. The reported statistics are for the set of 15,291 non-convertible corporate bond securities categorized as such by FISD. Data on bond credit ratings, issue sizes, and maturity dates came from FISD. The Own Ratio is calculated for each bond in a given year as the percentage of the total outstanding issue size held by all 2,268 bond mutual funds. The Own Number is calculated for each bond in a given year as the number of funds holding that bond. As in Falkenstein (1996), both these variables are calculated every year and use the latest holdings report in a given year for a given mutual fund. The average and median values reported below are taken across year-bond observations (there are 71,568 year-bond observations). Panel A reports ownership statistics for all bonds. Panel B reports mean and median values for the ownership statistics by credit rating group. Each credit rating group is constructed such that, for example, all AAA-, AAA, and AAA+ bonds are categorized as one group, AAA. Panel $\mathrm{C}$ reports statistics categorized by the size of the issue. Each year bonds are ranked on issue size and sorted into deciles where the highest-issue-size bonds are placed in Decile 1 and lowest-issue-size bonds are placed in Decile 10. Ownership statistics categorized into 4 groups defined by the time to maturity are reported in Panel D.

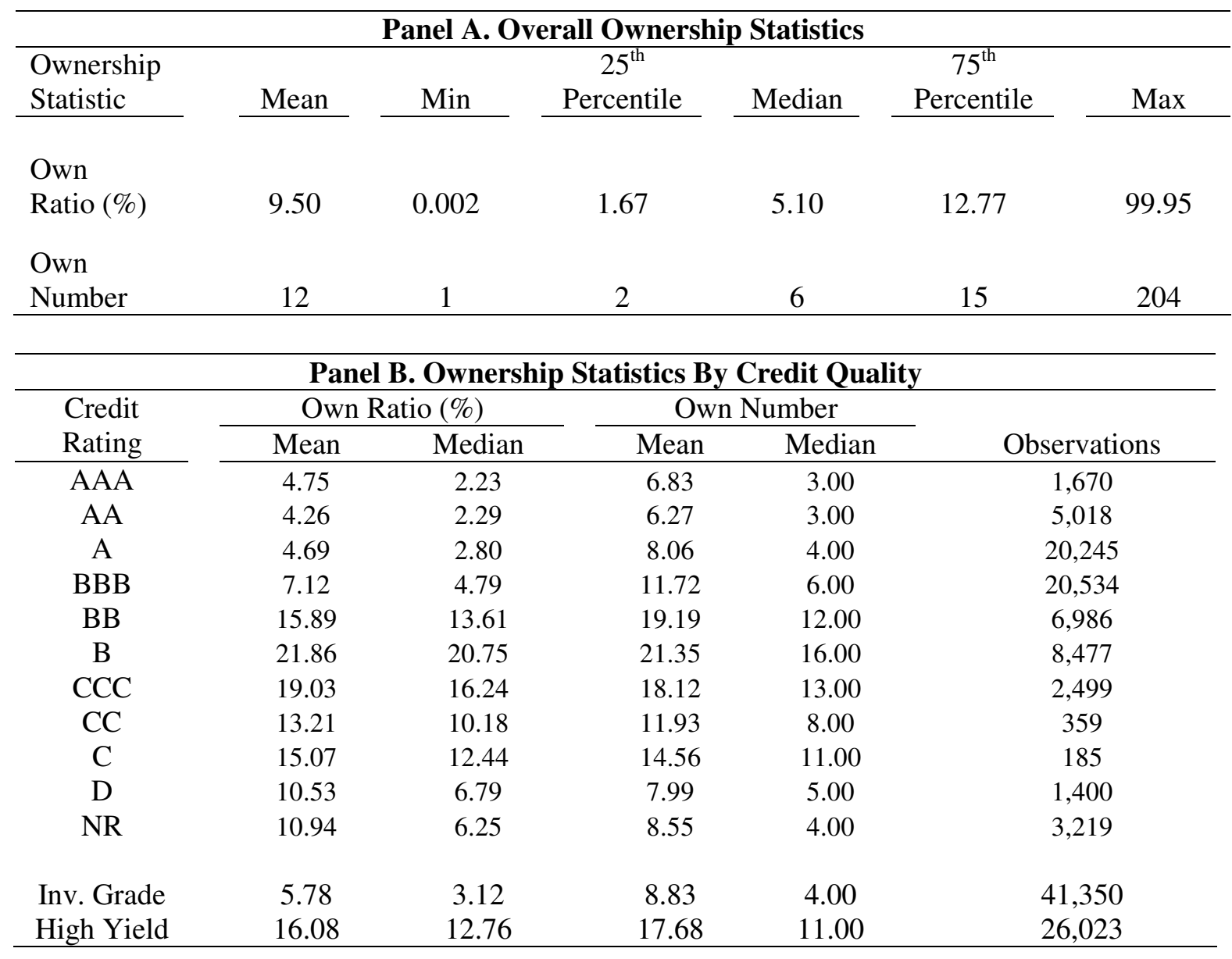




\section{Table I-Continued}

\begin{tabular}{|c|c|c|c|c|c|}
\hline \multicolumn{6}{|c|}{ Panel B. Ownership Statistics By Issue Size } \\
\hline \multirow{2}{*}{$\begin{array}{l}\text { Issue Size } \\
\text { Decile }\end{array}$} & \multicolumn{2}{|c|}{ Own Ratio (\%) } & \multicolumn{2}{|c|}{ Own Number } & \multirow[b]{2}{*}{ Observations } \\
\hline & Mean & Median & Mean & Median & \\
\hline 1 (Highest) & 7.29 & 5.14 & 29.61 & 21.00 & 7,306 \\
\hline 2 & 8.58 & 5.42 & 18.36 & 13.00 & 7,295 \\
\hline 3 & 9.18 & 5.35 & 15.29 & 10.00 & 6,831 \\
\hline 4 & 9.62 & 5.21 & 13.36 & 8.00 & 6,815 \\
\hline 5 & 8.78 & 4.47 & 9.57 & 5.00 & 8,543 \\
\hline 6 & 9.88 & 4.86 & 9.07 & 5.00 & 6,300 \\
\hline 7 & 10.33 & 5.20 & 8.76 & 5.00 & 7,406 \\
\hline 8 & 11.44 & 6.28 & 8.40 & 5.00 & 6,223 \\
\hline 9 & 9.80 & 5.00 & 5.19 & 3.00 & 8,073 \\
\hline 10(Lowest) & 10.58 & 4.80 & 2.70 & 1.00 & 6,776 \\
\hline
\end{tabular}

\begin{tabular}{|c|c|c|c|c|c|}
\hline \multicolumn{6}{|c|}{ Panel C. Ownership Statistics By Time to Maturity } \\
\hline \multirow{2}{*}{$\begin{array}{l}\text { Time to } \\
\text { Maturity }\end{array}$} & \multicolumn{2}{|c|}{ Own Ratio (\%) } & \multicolumn{2}{|c|}{ Own Number } & \multirow[b]{2}{*}{ Observations } \\
\hline & Mean & Median & Mean & Median & \\
\hline$\leq 2$ years & 7.08 & 3.66 & 8.14 & 4.00 & 16,003 \\
\hline$(2,5]$ & 9.55 & 5.70 & 12.55 & 7.00 & 19,350 \\
\hline$(5,10]$ & 13.08 & 7.67 & 16.65 & 9.00 & 22,846 \\
\hline$>10$ years & 6.19 & 3.59 & 8.18 & 4.00 & 13,157 \\
\hline
\end{tabular}




\section{Table II}

\section{Bond Price Dispersion-Univariate Sorts}

This table reports price dispersion statistics for bonds that are held by at least 3 mutual funds at the same date. There are 252,765 bond-date observations that satisfy this condition, corresponding to 11,116 corporate bonds. For a particular bond at a particular date we calculate the interquartile range (IR), standard deviation (STD), and the average median absolute deviation (MAD) of the prices reported by the various mutual funds that reported ownership of that bond. The resulting dispersion statistics are then averaged across bond-date observations. Panel A reports dispersion statistics by credit rating group. Each credit rating group is constructed such that, for example, all AAA-, AAA, and AAA+ bonds are categorized as one group, AAA. Panel B reports statistics categorized by the size of the issue. Each year bonds are ranked on issue size and sorted into deciles where the highest-issue-size bonds are placed in Decile 1 and lowest-issuesize bonds are placed in Decile 10. Panel C reports dispersion statistics categorized into 4 groups defined by the time to maturity.

\begin{tabular}{|c|c|c|c|c|}
\hline \multicolumn{5}{|c|}{ Panel A. Price Dispersion Statistics By Credit Quality } \\
\hline \multirow{2}{*}{$\begin{array}{l}\text { Credit } \\
\text { Rating }\end{array}$} & \multicolumn{3}{|c|}{ Mean of Dispersion Measures } & \multirow[b]{2}{*}{ Observations } \\
\hline & IR & STD & MAD & \\
\hline AAA & 0.228 & 0.179 & 0.109 & 4,211 \\
\hline $\mathrm{AA}$ & 0.255 & 0.199 & 0.122 & 10,874 \\
\hline A & 0.281 & 0.232 & 0.140 & 59,612 \\
\hline BBB & 0.332 & 0.280 & 0.170 & 73,847 \\
\hline $\mathrm{BB}$ & 0.542 & 0.467 & 0.286 & 32,831 \\
\hline B & 0.554 & 0.473 & 0.296 & 46,754 \\
\hline $\mathrm{CCC}$ & 0.604 & 0.496 & 0.312 & 11,350 \\
\hline $\mathrm{CC}$ & 0.679 & 0.568 & 0.347 & 911 \\
\hline $\mathrm{C}$ & 0.712 & 0.568 & 0.355 & 620 \\
\hline D & 0.571 & 0.455 & 0.279 & 3,674 \\
\hline NR & 0.503 & 0.385 & 0.244 & 6,733 \\
\hline Inv. Grade & 0.290 & 0.240 & 0.145 & 126,836 \\
\hline High Yield & 0.525 & 0.446 & 0.276 & 117,848 \\
\hline
\end{tabular}




\section{Table II-Continued}

\begin{tabular}{ccccc}
\hline & \multicolumn{3}{c}{ Panel B. Price Dispersion Statistics By Issue Size } \\
\cline { 4 - 5 } Issue Size & \multicolumn{3}{c}{ Mean of Dispersion Measures } \\
\cline { 4 - 5 } Decile & IR & STD & MAD & Observations \\
\cline { 4 - 5 } \cline { 4 - 5 } 1 (Highest) & 0.241 & 0.261 & 0.149 & 24,105 \\
2 & 0.301 & 0.286 & 0.172 & 26,434 \\
3 & 0.369 & 0.321 & 0.197 & 23,500 \\
4 & 0.370 & 0.319 & 0.197 & 27,525 \\
5 & 0.436 & 0.362 & 0.225 & 24,603 \\
6 & 0.422 & 0.343 & 0.214 & 25,650 \\
7 & 0.442 & 0.354 & 0.220 & 24,757 \\
8 & 0.454 & 0.363 & 0.226 & 26,842 \\
9 & 0.513 & 0.413 & 0.256 & 24,056 \\
10 (Lowest) & 0.511 & 0.384 & 0.238 & 25,293 \\
\hline
\end{tabular}

\begin{tabular}{|c|c|c|c|c|}
\hline \multicolumn{5}{|c|}{ Panel C. Price Dispersion Statistics By Time to Maturity } \\
\hline \multirow{2}{*}{$\begin{array}{l}\text { Time to } \\
\text { Maturity }\end{array}$} & \multicolumn{3}{|c|}{ Mean of Dispersion Measures } & \multirow[b]{2}{*}{ Observations } \\
\hline & IR & STD & MAD & \\
\hline$\leq 2$ years & 0.192 & 0.168 & 0.099 & 42,766 \\
\hline$(2,5]$ & 0.369 & 0.315 & 0.191 & 71,938 \\
\hline$(5,10]$ & 0.472 & 0.401 & 0.249 & 100,788 \\
\hline$>10$ years & 0.546 & 0.426 & 0.264 & 36,913 \\
\hline
\end{tabular}




\section{Table III}

\section{Bond Price Dispersion-Multivariate Analysis}

This table reports results from pooled regressions of bond price dispersion measures on several variables. The dispersion measures we use are the interquartile range (IR), standard deviation (STD), and the average median absolute deviation (MAD) of the prices reported by the various mutual funds that reported ownership of a particular bond at a particular date. Only bond-date observations where the bond is held by at least three mutual funds are included in the analysis and there are 252,765 bond-date observations corresponding to 11,116 bonds that satisfy this condition. The independent variables include Issue Size (log of the Original Face Value of a bond issue expressed in millions of dollars); Maturity (log of the difference between the period in which the price dispersion was measured and the maturity date of the bond expressed in years); Rating Code (a discrete variable ranging from 1 for AAA rated bonds to 22 for D rated bonds); Volatility (the annualized standard deviation of daily percentage price changes for the 10-year Treasury Note Futures); TRACE Transition Dummy which takes the value one when an observation occurs between July 1, 2002 and September 30, 2004 (the period over which TRACE was partially implemented) and zero in all other instances; and Full TRACE Dummy which takes the value one for all observations after September 30, 2004 (when TRACE was fully implemented) and zero otherwise. T-statistics, presented in parentheses, are based on Rogers (1993) standard errors clustered by bond.

\begin{tabular}{|c|c|c|c|c|c|c|}
\hline \multicolumn{7}{|c|}{ Price Dispersion Regressions } \\
\hline & \multicolumn{6}{|c|}{ Dependent Variable (Price Dispersion Measures) } \\
\hline $\begin{array}{c}\text { Independent } \\
\text { Variables }\end{array}$ & \multicolumn{2}{|c|}{ IR } & \multicolumn{2}{|c|}{ STD } & 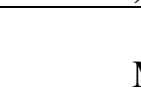 & \\
\hline Intercept & $\begin{array}{c}0.326 \\
(10.25)\end{array}$ & $\begin{array}{l}0.0584 \\
(18.84)\end{array}$ & $\begin{array}{l}-0.038 \\
(-1.71)\end{array}$ & $\begin{array}{l}0.121 \\
(5.47)\end{array}$ & $\begin{array}{l}0.001 \\
(0.08)\end{array}$ & $\begin{array}{l}0.109 \\
(8.15)\end{array}$ \\
\hline $\begin{array}{l}\text { Credit } \\
\text { Rating }\end{array}$ & $\begin{array}{c}0.020 \\
(23.00)\end{array}$ & $\begin{array}{c}0.022 \\
(26.06)\end{array}$ & $\begin{array}{c}0.021 \\
(34.03)\end{array}$ & $\begin{array}{c}0.022 \\
(36.59)\end{array}$ & $\begin{array}{c}0.013 \\
(34.30)\end{array}$ & $\begin{array}{c}0.014 \\
(37.39)\end{array}$ \\
\hline Issue Size & $\begin{array}{c}-0.080 \\
(-17.72)\end{array}$ & $\begin{array}{c}-0.064 \\
(-15.33)\end{array}$ & $\begin{array}{l}-0.016 \\
(-5.01)\end{array}$ & $\begin{array}{l}-0.007 \\
(-2.19)\end{array}$ & $\begin{array}{l}-0.016 \\
(-7.98)\end{array}$ & $\begin{array}{l}-0.009 \\
(-4.94)\end{array}$ \\
\hline Maturity & $\begin{array}{c}0.115 \\
(29.58)\end{array}$ & $\begin{array}{c}0.103 \\
(28.27)\end{array}$ & $\begin{array}{c}0.084 \\
(30.91)\end{array}$ & $\begin{array}{c}0.077 \\
(29.69)\end{array}$ & $\begin{array}{c}0.054 \\
(31.96)\end{array}$ & $\begin{array}{c}0.049 \\
(30.76)\end{array}$ \\
\hline Volatility & $\begin{array}{c}0.026 \\
(22.46)\end{array}$ & $\begin{array}{l}0.010 \\
(7.58)\end{array}$ & $\begin{array}{c}0.020 \\
(22.33)\end{array}$ & $\begin{array}{l}0.008 \\
(9.60)\end{array}$ & $\begin{array}{c}0.013 \\
(24.43)\end{array}$ & $\begin{array}{l}0.005 \\
(9.93)\end{array}$ \\
\hline $\begin{array}{c}\text { TRACE } \\
\text { Transition } \\
\text { Dummy }\end{array}$ & & $\begin{array}{c}-0.295 \\
(-35.26)\end{array}$ & & $\begin{array}{c}-0.156 \\
(-28.24)\end{array}$ & & $\begin{array}{c}-0.113 \\
(-31.78)\end{array}$ \\
\hline $\begin{array}{c}\text { Full Trace } \\
\text { Dummy }\end{array}$ & & $\begin{array}{c}-0.360 \\
(-40.74)\end{array}$ & & $\begin{array}{c}-0.209 \\
(-34.04)\end{array}$ & & $\begin{array}{c}-0.145 \\
(-37.55)\end{array}$ \\
\hline$R^{2}$ & $4.95 \%$ & $8.09 \%$ & $6.11 \%$ & $8.19 \%$ & $6.78 \%$ & $9.54 \%$ \\
\hline Observations & 239,447 & 239,447 & 239,447 & 239,447 & 239,447 & 239,447 \\
\hline
\end{tabular}




\section{Table IV \\ TRACE Regressions}

This table reports results from pooled regressions of bond price dispersion measures on several control variables and certain dummy variables created to capture the impact of TRACE on the dispersion of bond prices. The dispersion measures we use are the interquartile range (IR), standard deviation (STD), and average median absolute deviation (MAD) of the prices reported by the various mutual funds that reported ownership of a particular bond at a particular date. Only bond-date observations where the bond is held by at least three mutual funds are included in the analysis and there are 252,765 bond-date observations corresponding to 11,116 bonds that satisfy this condition. The control variables include Issue Size (log of the Original Face Value of a bond issue expressed in millions of dollars); Maturity (log of the difference between the period in which the price dispersion was measured and the maturity date of the bond expressed in years); Rating Code (a discrete variable ranging from 1 for AAA rated bonds to 22 for D rated bonds); and Volatility (the annualized standard deviation of daily percentage price changes for the 10-year Treasury Note Futures). The Set I specification includes all bonds conforming to the set of bonds that became permanently TRACE-eligible as of July 1, 2002 (all investment grade bonds greater than $\$ 1$ billion in original issue size). The Set II specification includes all bonds conforming to the set of bonds that became permanently TRACE-eligible as of March, 2003 (all investment grade bonds rated $\mathrm{A}$ or higher with original issue size of $\$ 100$ million or greater). Both Set I and II specifications are reported in Panel A. The remaining specification in Panel B includes all bonds with characteristics other than those shared by the bonds in Set I and II. The TRACE Eligible Dummy used in the Panel B equals one when a particular bond had a TRACE trade report during the July 1, 2002- September 30, 2004 period and zero in all the other instances. The TRACE Ineligible Dummy takes the value one if a bond did not have a TRACE trade report during the July 1, 2002- September 30, 2004 period and zero in all the other instances. The Full TRACE Dummy is one for all observations after September 30, 2004 (after which TRACE was fully implemented) and zero otherwise. The F-test in Panel B is based on the null hypothesis that the coefficients for TRACE Eligible and TRACE Ineligible Dummies are equal. T-statistics, presented in parentheses, are based on Rogers (1993) standard errors clustered by bond. 
Table IV-Continued

\begin{tabular}{|c|c|c|c|c|c|c|}
\hline \multicolumn{7}{|c|}{ Panel A. Set I and II Bonds } \\
\hline \multirow{2}{*}{$\begin{array}{l}\text { Independent } \\
\text { Variables }\end{array}$} & \multicolumn{3}{|c|}{ Set I Bonds } & \multicolumn{3}{|c|}{ Set II Bonds } \\
\hline & IR & STD & MAD & IR & STD & MAD \\
\hline Intercept & $\begin{array}{l}0.095 \\
(4.44)\end{array}$ & $\begin{array}{l}0.030 \\
(1.73)\end{array}$ & $\begin{array}{l}0.033 \\
(3.37)\end{array}$ & $\begin{array}{l}0.133 \\
(8.99)\end{array}$ & $\begin{array}{l}0.088 \\
(8.97)\end{array}$ & $\begin{array}{l}0.052 \\
(8.61)\end{array}$ \\
\hline Maturity & $\begin{array}{c}0.083 \\
(13.68)\end{array}$ & $\begin{array}{c}0.087 \\
(15.33)\end{array}$ & $\begin{array}{c}0.051 \\
(16.32)\end{array}$ & $\begin{array}{c}0.132 \\
(22.21)\end{array}$ & $\begin{array}{c}0.091 \\
(24.20)\end{array}$ & $\begin{array}{c}0.060 \\
(25.04)\end{array}$ \\
\hline Volatility & $\begin{array}{l}0.015 \\
(5.31)\end{array}$ & $\begin{array}{l}0.018 \\
(8.73)\end{array}$ & $\begin{array}{l}0.010 \\
(8.36)\end{array}$ & $\begin{array}{c}0.019 \\
(10.70)\end{array}$ & $\begin{array}{c}0.018 \\
(14.02)\end{array}$ & $\begin{array}{c}0.010 \\
(13.88)\end{array}$ \\
\hline $\begin{array}{l}\text { Full TRACE } \\
\text { Dummy }\end{array}$ & $\begin{array}{c}-0.146 \\
(-13.60)\end{array}$ & $\begin{array}{l}-0.057 \\
(-5.48)\end{array}$ & $\begin{array}{l}-0.058 \\
(-10.40)\end{array}$ & $\begin{array}{c}-0.241 \\
(-23.13)\end{array}$ & $\begin{array}{l}-0.155 \\
(-23.22)\end{array}$ & $\begin{array}{c}-0.098 \\
(-23.96)\end{array}$ \\
\hline$R^{2}$ & $7.48 \%$ & $6.77 \%$ & $9.42 \%$ & $8.26 \%$ & $8.69 \%$ & $9.75 \%$ \\
\hline Observations & 16,412 & 16,412 & 16,412 & 61,176 & 61,176 & 61,176 \\
\hline
\end{tabular}

\begin{tabular}{|c|c|c|c|c|c|c|}
\hline \multicolumn{7}{|c|}{ Panel B. Remaining Bonds } \\
\hline \multirow[b]{2}{*}{ Variables } & \multicolumn{3}{|c|}{ Set III: BBB Rated Bonds } & \multicolumn{3}{|c|}{ Set IV: Non-BBB Rated Bonds } \\
\hline & IR & STD & MAD & IR & STD & MAD \\
\hline Intercept & $\begin{array}{c}0.315 \\
(14.05)\end{array}$ & $\begin{array}{c}0.234 \\
(15.99)\end{array}$ & $\begin{array}{c}0.141 \\
(15.22)\end{array}$ & $\begin{array}{c}0.806 \\
(30.98)\end{array}$ & $\begin{array}{c}0.528 \\
(27.49)\end{array}$ & $\begin{array}{c}0.356 \\
(30.38)\end{array}$ \\
\hline Maturity & $\begin{array}{c}0.116 \\
(20.67)\end{array}$ & $\begin{array}{c}0.085 \\
(21.83)\end{array}$ & $\begin{array}{c}0.054 \\
(22.12)\end{array}$ & $\begin{array}{l}0.026 \\
(2.91)\end{array}$ & $\begin{array}{l}0.029 \\
(4.09)\end{array}$ & $\begin{array}{l}0.019 \\
(4.53)\end{array}$ \\
\hline Volatility & $\begin{array}{l}0.016 \\
(6.40)\end{array}$ & $\begin{array}{l}0.009 \\
(5.55)\end{array}$ & $\begin{array}{l}0.007 \\
(6.82)\end{array}$ & $\begin{array}{l}0.005 \\
(2.16)\end{array}$ & $\begin{array}{l}0.011 \\
(7.07)\end{array}$ & $\begin{array}{l}0.005 \\
(5.29)\end{array}$ \\
\hline $\begin{array}{l}\text { TRACE } \\
\text { Eligible Dummy }\end{array}$ & $\begin{array}{c}-0.365 \\
(-20.59)\end{array}$ & $\begin{array}{c}-0.163 \\
(-11.47)\end{array}$ & $\begin{array}{c}-0.126 \\
(-15.27)\end{array}$ & $\begin{array}{l}-0.405 \\
(-20.73)\end{array}$ & $\begin{array}{c}-0.217 \\
(-13.07)\end{array}$ & $\begin{array}{l}-0.152 \\
(-16.44)\end{array}$ \\
\hline $\begin{array}{l}\text { TRACE } \\
\text { Ineligible Dummy }\end{array}$ & $\begin{array}{c}-0.299 \\
(-18.72)\end{array}$ & $\begin{array}{l}-0.155 \\
(-14.49)\end{array}$ & $\begin{array}{l}-0.110 \\
(-16.28)\end{array}$ & $\begin{array}{c}-0.373 \\
(-24.29)\end{array}$ & $\begin{array}{l}-0.215 \\
(-21.93)\end{array}$ & $\begin{array}{c}-0.151 \\
(-23.41)\end{array}$ \\
\hline $\begin{array}{l}\text { Full TRACE } \\
\text { Dummy }\end{array}$ & $\begin{array}{c}-0.373 \\
(-22.41)\end{array}$ & $\begin{array}{c}-0.237 \\
(-21.50)\end{array}$ & $\begin{array}{c}-0.154 \\
(-21.98)\end{array}$ & $\begin{array}{c}-0.457 \\
(-28.39)\end{array}$ & $\begin{array}{c}-0.223 \\
(-19.29)\end{array}$ & $\begin{array}{l}-0.172 \\
(-23.98)\end{array}$ \\
\hline $\begin{array}{l}R^{2} \\
\text { Observations }\end{array}$ & $\begin{array}{l}6.64 \% \\
66,089\end{array}$ & $\begin{array}{l}6.71 \% \\
66,089\end{array}$ & $\begin{array}{l}7.18 \% \\
66,089\end{array}$ & $\begin{array}{l}4.60 \% \\
95,352\end{array}$ & $\begin{array}{l}2.81 \% \\
95,352\end{array}$ & $\begin{array}{l}4.08 \% \\
95,352\end{array}$ \\
\hline $\begin{array}{l}\text { F statistic } \\
\text { probabilities }\end{array}$ & 0.0001 & 0.2882 & 0.0016 & 0.055 & 0.915 & 0.912 \\
\hline
\end{tabular}




\section{Table V \\ Frequency Analysis by Pricing Standard}

Table V reports the frequency of funds in each of the six categories classified by pricing standard. Funds are classified using a three-step process. First, the mark of each bond held is determined to be above or below the consensus price for each fund on each report date. Second, each fund date is screened for the systematic marking up of bonds using a binomial test based on the number of bonds marked up and the total number of bonds. Fund dates are recorded as "up dates" when the one-sided $p$-value from the binomial test is less than five percent under the null that marking individual positions above or below the consensus price is equally likely. Fund dates are recorded as "down dates" in a similar fashion. Thus, each date for which a fund reports portfolio holdings is categorized as either an "up date," a "down date," or "unclassified." Third, a fund is categorized as a mid marker if no date for that fund can be categorized as a "down date" and the rest of the dates are categorized as a mixture of "up dates" and "unclassified dates." A fund is categorized as a bid marker if no date for that fund can be categorized as an "up date" and the rest of the dates are categorized as a mixture of "down dates" and "unclassified dates." A fund is classified as a bid-to-mid switcher if at a particular point in time the classification of its portfolio dates changed from "down dates" to "up dates". A fund is categorized as a mid-to-bid switcher in a similar way. Finally, a volatile marker is a fund that experienced multiple changes in the classification of its portfolio holdings report dates from "down dates" to "up dates" or vice versa. To ensure that our inferences are based on sufficient data, our sample only includes dates when funds report holdings for ten or more bonds with valid consensus prices. Panels A.1 and B.1 make use of all bonds in the each mutual fund portfolio whereas Panels A.2 and B.2 use only the 20 corporate bonds with the least amount of expected bond price dispersion. Expected price dispersion for a given bond is calculated from a pooled regression of the interquartile range (IR) of prices reported by the all funds holding the same bond on the same date on a set of independent variables including: Issue Size (log of the original face value of a bond issue expressed in millions of dollars); Maturity (log of the remaining time to maturity of the bond expressed in years); Rating Code (a discrete variable ranging from 1 for AAA rated bonds to 22 for D rated bonds); and Volatility (the annualized standard deviation of daily percentage price changes for the 10-year Treasury Note Futures). 
Panel A. Frequency by Pricing Standard

Panel A.1. All Bonds in the Portfolio Included

\begin{tabular}{|c|c|c|c|c|c|c|}
\hline \multirow[b]{2}{*}{ Pricing Standard } & \multicolumn{2}{|c|}{ 01/31/1995-12/31/2006 } & \multicolumn{2}{|c|}{ 01/31/1995-06/30/2002 } & \multicolumn{2}{|c|}{$10 / 31 / 2004-12 / 31 / 2006$} \\
\hline & \multicolumn{2}{|c|}{$\begin{array}{l}\# \\
\%\end{array}$} & \# & $\%$ & \multicolumn{2}{|c|}{ \# $\%$} \\
\hline Mid Markers & 256 & 27.53 & 205 & 29.04 & 265 & 34.78 \\
\hline Bid Markers & 335 & 36.02 & 269 & 38.1 & 321 & 42.13 \\
\hline Unclassifiable & 74 & 7.96 & 148 & 20.96 & 89 & 11.68 \\
\hline Bid to Mid Switchers & 53 & 5.7 & 19 & 2.69 & 28 & 3.67 \\
\hline Mid to Bid Switchers & 56 & 6.02 & 18 & 2.55 & 20 & 2.62 \\
\hline Volatile Markers & 156 & 16.77 & 47 & 6.66 & 39 & 5.12 \\
\hline Total & 930 & $100 \%$ & 706 & $100 \%$ & 762 & $100 \%$ \\
\hline \multicolumn{7}{|c|}{ Panel A.2. Top 20 Bonds with Least Expected Pricing Dispersion in Portfolio Included } \\
\hline & \multicolumn{2}{|c|}{$01 / 31 / 1995-12 / 31 / 2006$} & \multicolumn{2}{|c|}{$01 / 31 / 1995-06 / 30 / 2002$} & \multicolumn{2}{|c|}{$10 / 31 / 2004-12 / 31 / 2006$} \\
\hline Pricing Standard & \# & $\%$ & \# & $\%$ & \# & $\%$ \\
\hline Mid Markers & 260 & 27.96 & 208 & 29.5 & 286 & 37.68 \\
\hline Bid Markers & 302 & 32.47 & 268 & 38.01 & 300 & 39.53 \\
\hline Unclassifiable & 77 & 8.28 & 150 & 21.28 & 85 & 11.2 \\
\hline Bid to Mid Switchers & 72 & 7.74 & 19 & 2.7 & 33 & 4.35 \\
\hline Mid to Bid Switchers & 68 & 7.31 & 23 & 3.26 & 24 & 3.16 \\
\hline Volatile Markers & 151 & 16.24 & 37 & 5.25 & 31 & 4.08 \\
\hline Total & 930 & $100 \%$ & 705 & $100 \%$ & 759 & $100 \%$ \\
\hline
\end{tabular}




\section{Panel B. Contingency Table}

Panel B.1. All Bonds in the Portfolio Included

\begin{tabular}{|c|c|c|c|c|c|c|c|c|c|c|c|c|c|c|}
\hline \multirow[b]{3}{*}{$01 / 31 / 1995-06 / 30 / 2002$} & \multicolumn{14}{|c|}{$10 / 31 / 2004-12 / 31 / 2006$} \\
\hline & \multicolumn{2}{|c|}{ Mid Markers } & \multicolumn{2}{|c|}{ Bid Markers } & \multicolumn{2}{|c|}{ Unclassifiable } & \multicolumn{2}{|c|}{$\begin{array}{l}\text { Bid-to-Mid } \\
\text { Switchers }\end{array}$} & \multicolumn{2}{|c|}{$\begin{array}{l}\text { Mid-to-Bid } \\
\text { Switchers }\end{array}$} & \multicolumn{2}{|c|}{$\begin{array}{l}\text { Volatile } \\
\text { Markers }\end{array}$} & \multicolumn{2}{|c|}{$\begin{array}{l}\text { Dead } \\
\text { Funds }\end{array}$} \\
\hline & \# & $\%$ & \# & $\%$ & $\#$ & $\%$ & $\#$ & $\%$ & $\#$ & $\%$ & $\#$ & $\%$ & \# & $\%$ \\
\hline Mid Markers & 118 & 57.56 & 26 & 12.68 & 4 & 1.95 & 2 & 0.98 & 5 & 2.44 & 10 & 4.88 & 40 & 19.51 \\
\hline Bid Markers & 16 & 5.95 & 150 & 55.76 & 27 & 10.04 & 11 & 4.09 & 5 & 1.86 & 10 & 3.72 & 50 & 18.59 \\
\hline Unclassifiable & 30 & 20.27 & 42 & 28.38 & 23 & 15.54 & 1 & 0.68 & 3 & 2.03 & 7 & 4.73 & 42 & 28.38 \\
\hline Bid-to-Mid Switchers & 8 & 42.11 & 3 & 15.79 & 1 & 5.26 & 1 & 5.26 & 1 & 5.26 & 1 & 5.26 & 4 & 21.05 \\
\hline Mid-to-Bid Switchers & 2 & 11.11 & 12 & 66.67 & 0 & 0.00 & 1 & 5.56 & 2 & 11.11 & 0 & 0.00 & 1 & 5.56 \\
\hline Volatile Markers & 12 & 25.53 & 20 & 42.55 & 2 & 4.26 & 2 & 4.26 & 2 & 4.26 & 4 & 8.51 & 5 & 10.64 \\
\hline
\end{tabular}

Panel B.2. Top 20 Bonds with Least Expected Pricing Dispersion in Portfolio Included

\begin{tabular}{|c|c|c|c|c|c|c|c|c|c|c|c|c|c|c|}
\hline \multirow[b]{3}{*}{ 01/31/1995-06/30/2002 } & \multicolumn{14}{|c|}{$10 / 31 / 2004-12 / 31 / 2006$} \\
\hline & \multicolumn{2}{|c|}{ Mid Markers } & \multicolumn{2}{|c|}{ Bid Markers } & \multicolumn{2}{|c|}{ Unclassifiable } & \multicolumn{2}{|c|}{$\begin{array}{l}\text { Bid-to-Mid } \\
\text { Switchers }\end{array}$} & \multicolumn{2}{|c|}{$\begin{array}{c}\text { Mid-to-Bid } \\
\text { Switchers }\end{array}$} & \multicolumn{2}{|c|}{$\begin{array}{l}\text { Volatile } \\
\text { Markers }\end{array}$} & \multicolumn{2}{|c|}{$\begin{array}{l}\text { Dead } \\
\text { Funds }\end{array}$} \\
\hline & \# & $\%$ & $\#$ & $\%$ & $\#$ & $\%$ & \# & $\%$ & \# & $\%$ & \# & $\%$ & \# & $\%$ \\
\hline Mid Markers & 124 & 59.62 & 24 & 11.54 & 8 & 3.85 & 3 & 1.44 & 6 & 2.88 & 5 & 2.40 & 38 & 18.27 \\
\hline Bid Markers & 26 & 9.70 & 135 & 50.37 & 26 & 9.70 & 11 & 4.10 & 7 & 2.61 & 14 & 5.22 & 49 & 18.28 \\
\hline Unclassifiable & 30 & 20.00 & 56 & 37.33 & 13 & 8.67 & 3 & 2.00 & 2 & 1.33 & 4 & 2.67 & 42 & 28.00 \\
\hline Bid-to-Mid Switchers & 10 & 52.63 & 0 & 0.00 & 3 & 15.79 & 0 & 0.00 & 1 & 5.26 & 0 & 0.00 & 5 & 26.32 \\
\hline Mid-to-Bid Switchers & 3 & 13.04 & 10 & 43.48 & 1 & 4.35 & 2 & 8.70 & 2 & 8.70 & 0 & 0.00 & 5 & 21.74 \\
\hline Volatile Markers & 13 & 35.14 & 13 & 35.14 & 1 & 2.70 & 2 & 5.41 & 2 & 5.41 & 1 & 2.70 & 5 & 13.51 \\
\hline
\end{tabular}




\section{Table VI}

\section{Price Dispersion Computed Holding Pricing Standard Constant}

This table reports results from pooled regressions of bond price dispersion measures (IR, STD, MAD) on control variables and Trace dummy variables as specified in Table IV. The price dispersion statistics in Panels A and B are based on all bond prices reported by presumed midmarking funds and presumed bid-marking funds, respectively. Funds are classified as presumed mid-marking or bid-marking using a three-step process. First, for each fund each portfolio date, the mark of each bond held is determined to be above or below the consensus price. Second, each fund date is screened for the systematic marking up of bonds using a binomial test based on the number of bonds marked up and the total number of bonds. Fund dates are recorded as "up dates" when the one-sided $p$-value from the binomial test is less than five percent under the null that marking individual positions above or below the consensus price is equally likely. Fund dates are recorded as "down dates" in a similar fashion. Thus, each date for which a fund reports portfolio holdings is categorized as either an "up date," a "down date," or "unclassified." Third, a fund is categorized as a presumed mid-marker if at least one of the portfolio dates for that fund is categorized as an "up date" and the rest of the dates are categorized as "unclassified." A fund is categorized as a presumed bid marker if at least one of the portfolio dates for that fund is categorized as a "down date" and the rest of the dates are categorized as "unclassified." To ensure that our inferences are based on sufficient data, our sample only includes months when funds report holdings for ten or more bonds with valid consensus prices. T-statistics, presented in parentheses, are based on Rogers (1993) standard errors clustered by bond. 


\begin{tabular}{|c|c|c|c|c|c|c|}
\hline \multicolumn{7}{|c|}{ Panel A. Bond Prices Reported by Presumed Mid Marking Funds } \\
\hline \multicolumn{7}{|c|}{ Panel A.1. Set I and II Bonds } \\
\hline Independent & \multicolumn{3}{|c|}{ Set I Bonds } & \multicolumn{3}{|c|}{ Set II Bonds } \\
\hline Variables & IR & STD & MAD & IR & STD & MAD \\
\hline Intercept & $\begin{array}{l}0.072 \\
(4.57)\end{array}$ & $\begin{array}{l}0.023 \\
(1.65)\end{array}$ & $\begin{array}{l}0.020 \\
(2.76)\end{array}$ & $\begin{array}{l}0.083 \\
(2.92)\end{array}$ & $\begin{array}{l}0.050 \\
(3.04)\end{array}$ & $\begin{array}{l}0.028 \\
(2.84)\end{array}$ \\
\hline Maturity & $\begin{array}{l}0.008 \\
(2.39)\end{array}$ & $\begin{array}{l}0.019 \\
(6.21)\end{array}$ & $\begin{array}{l}0.008 \\
(5.62)\end{array}$ & $\begin{array}{l}0.015 \\
(1.32)\end{array}$ & $\begin{array}{l}0.009 \\
(1.40)\end{array}$ & $\begin{array}{l}0.005 \\
(1.42)\end{array}$ \\
\hline Volatility & $\begin{array}{l}0.000 \\
(-0.24)\end{array}$ & $\begin{array}{l}0.002 \\
(1.27)\end{array}$ & $\begin{array}{l}0.001 \\
(0.84)\end{array}$ & $\begin{array}{l}0.001 \\
(0.42)\end{array}$ & $\begin{array}{l}0.001 \\
(0.59)\end{array}$ & $\begin{array}{l}0.001 \\
(0.72)\end{array}$ \\
\hline $\begin{array}{l}\text { Full TRACE } \\
\text { Dummy }\end{array}$ & $\begin{array}{l}-0.068 \\
(-4.16)\end{array}$ & $\begin{array}{l}-0.042 \\
(-4.10)\end{array}$ & $\begin{array}{l}-0.026 \\
(-4.42)\end{array}$ & $\begin{array}{l}-0.075 \\
(-4.48)\end{array}$ & $\begin{array}{l}-0.046 \\
(-4.70)\end{array}$ & $\begin{array}{l}-0.26 \\
(-4.50)\end{array}$ \\
\hline $\begin{array}{l}R^{2} \\
\text { Observations }\end{array}$ & $\begin{array}{l}1.59 \% \\
5,179\end{array}$ & $\begin{array}{c}1.89 \% \\
5,179\end{array}$ & $\begin{array}{c}2.01 \% \\
5,179\end{array}$ & $\begin{array}{l}1.82 \% \\
4,009\end{array}$ & $\begin{array}{l}1.95 \% \\
4,009\end{array}$ & $\begin{array}{l}1.77 \% \\
4,009\end{array}$ \\
\hline \multicolumn{7}{|c|}{ Panel A.2. Set III and IV Bonds } \\
\hline & \multicolumn{3}{|c|}{ Set III: BBB Rated Bonds } & \multicolumn{3}{|c|}{ Set IV: Non-BBB Rated Bonds } \\
\hline Variables & IR & STD & MAD & IR & STD & MAD \\
\hline Intercept & $\begin{array}{l}0.188 \\
(4.46)\end{array}$ & $\begin{array}{l}0.119 \\
(4.90)\end{array}$ & $\begin{array}{l}0.072 \\
(4.90)\end{array}$ & $\begin{array}{c}0.337 \\
(10.62)\end{array}$ & $\begin{array}{l}0.204 \\
(10.07)\end{array}$ & $\begin{array}{c}0.132 \\
(10.38)\end{array}$ \\
\hline Maturity & $\begin{array}{l}0.029 \\
(3.61)\end{array}$ & $\begin{array}{l}0.021 \\
(4.33)\end{array}$ & $\begin{array}{l}0.012 \\
(3.99)\end{array}$ & $\begin{array}{l}0.011 \\
(1.65)\end{array}$ & $\begin{array}{l}0.022 \\
(4.51)\end{array}$ & $\begin{array}{l}0.010 \\
(3.83)\end{array}$ \\
\hline Volatility & $\begin{array}{l}-0.004 \\
(-1.33)\end{array}$ & $\begin{array}{l}-0.002 \\
(-0.77)\end{array}$ & $\begin{array}{l}-0.001 \\
(-0.92)\end{array}$ & $\begin{array}{l}-0.002 \\
(-0.90)\end{array}$ & $\begin{array}{l}0.003 \\
(1.96)\end{array}$ & $\begin{array}{l}0.001 \\
(0.90)\end{array}$ \\
\hline $\begin{array}{l}\text { TRACE } \\
\text { Eligible Dummy }\end{array}$ & $\begin{array}{l}-0.129 \\
(-3.68)\end{array}$ & $\begin{array}{l}-0.084 \\
(-3.74)\end{array}$ & $\begin{array}{l}-0.051 \\
(-3.84)\end{array}$ & $\begin{array}{c}-0.282 \\
(-11.79)\end{array}$ & $\begin{array}{c}-0.171 \\
(-10.91)\end{array}$ & $\begin{array}{l}-0.112 \\
(-11.36)\end{array}$ \\
\hline $\begin{array}{l}\text { TRACE } \\
\text { Ineligible Dummy }\end{array}$ & $\begin{array}{l}-0.114 \\
(-3.92)\end{array}$ & $\begin{array}{l}-0.070 \\
(-3.80)\end{array}$ & $\begin{array}{l}-0.043 \\
(-3.87)\end{array}$ & $\begin{array}{l}-0.237 \\
(-12.14)\end{array}$ & $\begin{array}{c}-0.152 \\
(-12.65)\end{array}$ & $\begin{array}{l}-0.099 \\
(-12.58)\end{array}$ \\
\hline $\begin{array}{l}\text { Full TRACE } \\
\text { Dummy }\end{array}$ & $\begin{array}{l}-0.188 \\
(-5.24)\end{array}$ & $\begin{array}{l}-0.125 \\
(-5.85)\end{array}$ & $\begin{array}{l}-0.075 \\
(-5.87)\end{array}$ & $\begin{array}{l}-0.315 \\
(-14.07)\end{array}$ & $\begin{array}{l}-0.210 \\
(-15.33)\end{array}$ & $\begin{array}{l}-0.133 \\
(-14.89)\end{array}$ \\
\hline $\begin{array}{l}R^{2} \\
\text { Observations }\end{array}$ & $2.21 \%$ & $2.54 \%$ & $2.54 \%$ & $\begin{array}{l}4.32 \% \\
41104\end{array}$ & $4.39 \%$ & $4.73 \%$ \\
\hline $\begin{array}{l}\text { F statistic } \\
\text { probabilities }\end{array}$ & $\begin{array}{c}0,204 \\
0.31\end{array}$ & $\begin{array}{c}0,204 \\
0.14\end{array}$ & $\begin{array}{l}0,204 \\
0.16\end{array}$ & 0.0002 & 0.03 & 0.006 \\
\hline
\end{tabular}




\begin{tabular}{|c|c|c|c|c|c|c|}
\hline \multicolumn{7}{|c|}{ Panel B. Bond Prices Reported by Presumed Bid Marking Funds } \\
\hline \multicolumn{7}{|c|}{ Panel B.1. Set I and II Bonds } \\
\hline Independent & \multicolumn{3}{|c|}{ Set I Bonds } & \multicolumn{3}{|c|}{ Set II Bonds } \\
\hline Variables & IR & STD & MAD & IR & STD & MAD \\
\hline Intercept & $\begin{array}{l}0.094 \\
(3.99)\end{array}$ & $\begin{array}{l}0.047 \\
(3.00)\end{array}$ & $\begin{array}{l}0.031 \\
(3.26)\end{array}$ & $\begin{array}{l}0.195 \\
(6.84)\end{array}$ & $\begin{array}{l}0.119 \\
(6.99)\end{array}$ & $\begin{array}{l}0.073 \\
(7.13)\end{array}$ \\
\hline Maturity & $\begin{array}{l}0.027 \\
(3.79)\end{array}$ & $\begin{array}{l}0.028 \\
(5.32)\end{array}$ & $\begin{array}{l}0.016 \\
(4.99)\end{array}$ & $\begin{array}{l}0.035 \\
(3.30)\end{array}$ & $\begin{array}{l}0.024 \\
(3.76)\end{array}$ & $\begin{array}{l}0.014 \\
(3.50)\end{array}$ \\
\hline Volatility & $\begin{array}{l}0.026 \\
(9.06)\end{array}$ & $\begin{array}{l}0.020 \\
(11.17)\end{array}$ & $\begin{array}{c}0.013 \\
(11.12)\end{array}$ & $\begin{array}{l}0.014 \\
(4.54)\end{array}$ & $\begin{array}{l}0.010 \\
(5.57)\end{array}$ & $\begin{array}{l}0.006 \\
(5.67)\end{array}$ \\
\hline $\begin{array}{l}\text { Full TRACE } \\
\text { Dummy }\end{array}$ & $\begin{array}{c}-0.223 \\
(-10.34)\end{array}$ & $\begin{array}{l}-0.140 \\
(-10.18)\end{array}$ & $\begin{array}{l}-0.093 \\
(-10.29)\end{array}$ & $\begin{array}{c}-0.253 \\
(-12.26)\end{array}$ & $\begin{array}{c}-0.162 \\
(-12.90)\end{array}$ & $\begin{array}{l}-0.099 \\
(-13.04)\end{array}$ \\
\hline $\begin{array}{l}R^{2} \\
\text { Observations }\end{array}$ & $6.99 \%$ & $\begin{array}{l}8.35 \% \\
7.350\end{array}$ & $\begin{array}{l}8.38 \% \\
7350\end{array}$ & $\begin{array}{l}8.73 \% \\
7.152\end{array}$ & $\begin{array}{l}9.91 \% \\
7.152\end{array}$ & $\begin{array}{c}10.22 \% \\
7.152\end{array}$ \\
\hline \multicolumn{7}{|c|}{ Panel B.2. Set III and IV Bonds } \\
\hline & \multicolumn{3}{|c|}{ Set III: BBB Rated Bonds } & \multicolumn{3}{|c|}{ Set IV: Non-BBB Rated Bonds } \\
\hline Variables & IR & STD & MAD & IR & STD & MAD \\
\hline Intercept & $\begin{array}{l}0.260 \\
(5.82)\end{array}$ & $\begin{array}{l}0.168 \\
(6.08)\end{array}$ & $\begin{array}{l}0.099 \\
(5.58)\end{array}$ & $\begin{array}{c}0.631 \\
(14.52)\end{array}$ & $\begin{array}{c}0.390 \\
(13.85)\end{array}$ & $\begin{array}{c}0.242 \\
(14.12)\end{array}$ \\
\hline Maturity & $\begin{array}{l}0.033 \\
(4.55)\end{array}$ & $\begin{array}{l}0.027 \\
(5.49)\end{array}$ & $\begin{array}{l}0.015 \\
(5.07)\end{array}$ & $\begin{array}{l}0.018 \\
(1.91)\end{array}$ & $\begin{array}{l}0.026 \\
(4.02)\end{array}$ & $\begin{array}{l}0.015 \\
(3.75)\end{array}$ \\
\hline Volatility & $\begin{array}{l}0.017 \\
(3.69)\end{array}$ & $\begin{array}{l}0.011 \\
(4.01)\end{array}$ & $\begin{array}{l}0.008 \\
(4.29)\end{array}$ & $\begin{array}{l}-0.011 \\
(-3.16)\end{array}$ & $\begin{array}{l}-0.004 \\
(-1.82)\end{array}$ & $\begin{array}{l}-0.003 \\
(-2.20)\end{array}$ \\
\hline $\begin{array}{l}\text { TRACE } \\
\text { Eligible Dummy }\end{array}$ & $\begin{array}{l}-0.299 \\
(-10.71)\end{array}$ & $\begin{array}{l}-0.179 \\
(-9.91)\end{array}$ & $\begin{array}{l}-0.111 \\
(-10.05)\end{array}$ & $\begin{array}{l}-0.452 \\
(-14.94)\end{array}$ & $\begin{array}{c}-0.253 \\
(-13.25)\end{array}$ & $\begin{array}{l}-0.166 \\
(-14.41)\end{array}$ \\
\hline $\begin{array}{l}\text { TRACE } \\
\text { Ineligible Dummy }\end{array}$ & $\begin{array}{l}-0.229 \\
(-8.69)\end{array}$ & $\begin{array}{l}-0.139 \\
(-8.52)\end{array}$ & $\begin{array}{l}-0.086 \\
(-8.54)\end{array}$ & $\begin{array}{l}-0.430 \\
(-15.74)\end{array}$ & $\begin{array}{l}-0.261 \\
(-15.57)\end{array}$ & $\begin{array}{l}-0.167 \\
(-16.18)\end{array}$ \\
\hline $\begin{array}{l}\text { Full TRACE } \\
\text { Dummy }\end{array}$ & $\begin{array}{c}-0.348 \\
(-12.57)\end{array}$ & $\begin{array}{r}-0.228 \\
(-13.11)\end{array}$ & $\begin{array}{l}-0.138 \\
(-12.78)\end{array}$ & $\begin{array}{l}-0.535 \\
(-18.49)\end{array}$ & $\begin{array}{c}-0.334 \\
(-18.45)\end{array}$ & $\begin{array}{l}-0.210 \\
(-18.93)\end{array}$ \\
\hline $\begin{array}{l}R^{2} \\
\text { Observations }\end{array}$ & $\begin{array}{c}6.63 \\
11,999\end{array}$ & $\begin{array}{c}7.37 \\
11,999\end{array}$ & $\begin{array}{c}7.21 \\
11,999\end{array}$ & $\begin{array}{c}8.04 \\
31,907\end{array}$ & $\begin{array}{c}7.47 \\
31,907\end{array}$ & $\begin{array}{c}8.54 \\
31,907\end{array}$ \\
\hline $\begin{array}{l}F \text { statistic } \\
\text { probabilities }\end{array}$ & $<0.0001$ & $<0.0001$ & $<0.0001$ & 0.124 & 0.364 & 0.854 \\
\hline
\end{tabular}




\section{Table VII \\ Return Smoothing Regressions}

This table reports coefficient estimates from the return smoothing model of Getmansky, Lo, and Makarov (2004) for two groups of funds: 'consistent marker' funds and 'volatile marker' funds. The specification for the regression model is

$$
R_{j, t}^{0}=\alpha+\theta_{0} R_{j, t}+\theta_{1} R_{j, t-1}+\theta_{2} R_{j, t-2}+\theta_{3} R_{j, t-3}+\varepsilon_{j, t}
$$

where $R_{j, t}^{0}$ and $R_{j, t}$ are the reported and consensus-based returns of fund $j$ during period $t$. To test for the difference of the $\theta_{0}$ coefficients for the two groups of funds, we use the following regression model in Panel A

$$
R_{j, t}^{0}=\alpha+\theta_{0} R_{j, t}+\tilde{\theta}_{0} R_{j, t} \times D_{j}+\theta_{1} R_{j, t-1}+\theta_{2} R_{j, t-2}+\theta_{3} R_{j, t-3}+\varepsilon_{j, t}
$$

where $D_{j}$ takes a value of one if a fund is classified as a Volatile Marker and 0 if it is classified as a Consistent Marker. Consistent Markers are funds that consistently followed a bid or mid pricing standard throughout the sample period, i.e., these are funds classified as presumed mid-marking or bid-marking funds throughout the whole sample period. Volatile Markers are funds that experienced multiple changes in the classification of their portfolio holdings report dates from "down dates" to "up dates" or vice versa as detailed in Table V. Panel A reports results when observations across funds and periods are pooled together. In Panel B, the parameter estimates from the return smoothing regressions are estimated, as in Fama-MacBeth, for each month separately and then averaged across months, with reported t-statistics based on the time series standard errors, which have been further corrected to account for serial correlation using the Newey-West correction. In Panel $\mathrm{C}$, the parameter estimates from the return smoothing regressions are estimated for each fund separately and then averaged across funds, with reported t-statistics based on the cross-sectional standard errors. In Panels A and C only funds with 15 or more valid (non-missing) observations are included and in Panel B only months with 15 or more valid observations are included in the regressions. Panels A.1, B.1, and C.1 estimate unrestricted models whereas Panels A.2, B.2, and C.2 estimate models where the coefficients $\left(\theta_{0}, \theta_{1}, \theta_{2}, \theta_{3}\right)$

\begin{tabular}{|c|c|c|c|c|c|c|}
\hline \multicolumn{7}{|c|}{ Panel A. Pooled Regressions } \\
\hline & \multicolumn{3}{|c|}{ Panel A.1. Unconstrained Model } & \multicolumn{3}{|c|}{$\begin{array}{l}\text { Panel A.2. Constrained Model with } \\
\qquad \theta_{0}+\theta_{1}+\theta_{2}+\theta_{3}=1\end{array}$} \\
\hline Variable & $\begin{array}{l}\text { Volatile } \\
\text { Markers }\end{array}$ & $\begin{array}{c}\text { Consistent } \\
\text { Markers }\end{array}$ & $\begin{array}{l}\text { Volatile + } \\
\text { Consistent } \\
\text { Markers }\end{array}$ & $\begin{array}{l}\text { Volatile } \\
\text { Markers }\end{array}$ & $\begin{array}{l}\text { Consistent } \\
\text { Markers }\end{array}$ & $\begin{array}{l}\text { Volatile + } \\
\text { Consistent } \\
\text { Markers }\end{array}$ \\
\hline Intercept & $\begin{array}{c}0.0004 \\
(3.94)\end{array}$ & $\begin{array}{l}0.0000 \\
(0.65)\end{array}$ & $\begin{array}{l}0.0002 \\
(4.14)\end{array}$ & $\begin{array}{l}0.0000 \\
(-0.52)\end{array}$ & $\begin{array}{l}0.0000 \\
(-0.28)\end{array}$ & $\begin{array}{c}-0.0002 \\
(-4.99)\end{array}$ \\
\hline$R_{j, t}$ & $\begin{array}{c}0.8751 \\
(145.62)\end{array}$ & $\begin{array}{c}0.9922 \\
(583.36)\end{array}$ & $\begin{array}{c}0.9866 \\
(325.11)\end{array}$ & $\begin{array}{c}0.8991 \\
(174.89)\end{array}$ & $\begin{array}{c}0.9935 \\
(667.45)\end{array}$ & $\begin{array}{c}0.9876 \\
(316.66)\end{array}$ \\
\hline$R_{j, t} \times D_{j}$ & -- & -- & $\begin{array}{l}-0.1036 \\
(-21.57)\end{array}$ & & & $\begin{array}{l}-0.0548 \\
(-13.51)\end{array}$ \\
\hline$R_{j, t-1}$ & $\begin{array}{l}0.0334 \\
(5.52)\end{array}$ & $\begin{array}{l}0.0059 \\
(3.44)\end{array}$ & $\begin{array}{l}0.0156 \\
(6.17)\end{array}$ & $\begin{array}{l}0.0561 \\
(10.59)\end{array}$ & $\begin{array}{c}0.0071 \\
(4.67)\end{array}$ & $\begin{array}{l}0.0338 \\
(14.23)\end{array}$ \\
\hline$R_{j, t-2}$ & $\begin{array}{c}-0.0041 \\
(-0.68)\end{array}$ & $\begin{array}{l}-0.0040 \\
(-2.33)\end{array}$ & $\begin{array}{c}-0.0043 \\
(-1.72)\end{array}$ & $\begin{array}{c}0.0185 \\
(3.52)\end{array}$ & $\begin{array}{c}-0.0028 \\
(-1.82)\end{array}$ & $\begin{array}{l}0.0138 \\
(5.85)\end{array}$ \\
\hline$R_{j, t-3}$ & $\begin{array}{l}0.0034 \\
(0.57)\end{array}$ & $\begin{array}{c}0.0009 \\
(0.53)\end{array}$ & $\begin{array}{l}0.0011 \\
(0.45)\end{array}$ & $\begin{array}{c}0.0263 \\
(5.09)\end{array}$ & $\begin{array}{c}0.0022 \\
(1.47)\end{array}$ & $\begin{array}{r}0.0197 \\
(8.40)\end{array}$ \\
\hline $\begin{array}{l}R^{2} \\
\# \text { of }\end{array}$ & $91.22 \%$ & $99.07 \%$ & $96.47 \%$ & $90.99 \%$ & $99.07 \%$ & $96.27 \%$ \\
\hline Funds & 2,224 & 3,380 & 5,604 & 2,224 & 3,380 & 5,604 \\
\hline
\end{tabular}
are constrained to sum to one. $T$-statistics are presented in parentheses. 


\section{Table VII -continued}

\begin{tabular}{|c|c|c|c|c|c|c|}
\hline \multicolumn{7}{|c|}{ Panel B. Coefficients Estimated Using Fama-MacBeth Estimation } \\
\hline & \multicolumn{3}{|c|}{ Panel B.1. Unconstrained Model } & \multicolumn{3}{|c|}{$\begin{array}{l}\text { Panel B.2. Constrained Model with } \\
\qquad \theta_{0}+\theta_{1}+\theta_{2}+\theta_{3}=1\end{array}$} \\
\hline Variable & $\begin{array}{l}\text { Volatile } \\
\text { Markers }\end{array}$ & $\begin{array}{c}\text { Consistent } \\
\text { Markers }\end{array}$ & $\begin{array}{c}\theta_{0} \\
\text { Difference }\end{array}$ & $\begin{array}{l}\text { Volatile } \\
\text { Markers }\end{array}$ & $\begin{array}{c}\text { Consistent } \\
\text { Markers }\end{array}$ & $\begin{array}{c}\theta_{0} \\
\text { Difference }\end{array}$ \\
\hline Intercept & $\begin{array}{r}0.0007 \\
(1.11)\end{array}$ & $\begin{array}{l}0.0003 \\
(1.40)\end{array}$ & & $\begin{array}{c}-0.0008 \\
(-1.35)\end{array}$ & $\begin{array}{l}0.0000 \\
(-0.11)\end{array}$ & \\
\hline$R_{j, t}$ & $\begin{array}{c}0.6459 \\
(18.90)\end{array}$ & $\begin{array}{l}0.9444 \\
(65.07)\end{array}$ & $\begin{array}{c}-0.2986 \\
(8.40)\end{array}$ & $\begin{array}{l}0.7116 \\
(25.03)\end{array}$ & $\begin{array}{c}0.9646 \\
(115.23)\end{array}$ & $\begin{array}{c}-0.2529 \\
(8.00)\end{array}$ \\
\hline$R_{j, t-1}$ & $\begin{array}{c}0.0686 \\
(2.39)\end{array}$ & $\begin{array}{l}0.0260 \\
(3.36)\end{array}$ & & $\begin{array}{l}0.1423 \\
(6.18)\end{array}$ & $\begin{array}{l}0.0260 \\
(3.78)\end{array}$ & \\
\hline$R_{j, t-2}$ & $\begin{array}{c}0.0434 \\
(1.28)\end{array}$ & $\begin{array}{l}0.0075 \\
(1.17)\end{array}$ & & $\begin{array}{l}0.0838 \\
(3.07)\end{array}$ & $\begin{array}{l}0.0129 \\
(2.24)\end{array}$ & \\
\hline$R_{j, t-3}$ & $\begin{array}{c}-0.0081 \\
(-0.26)\end{array}$ & $\begin{array}{c}-0.0134 \\
(-1.28)\end{array}$ & & $\begin{array}{l}0.0623 \\
(2.22)\end{array}$ & $\begin{array}{c}-0.0034 \\
(-0.61)\end{array}$ & \\
\hline & -0.2600 & $97.78 \%$ & & $77.27 \%$ & $97.38 \%$ & \\
\hline Months & 67 & 67 & & 67 & 67 & \\
\hline \multicolumn{7}{|c|}{ Panel C. Coefficients Estimated for Each Fund } \\
\hline & \multicolumn{3}{|c|}{ Panel C.1. Unconstrained Model } & \multicolumn{3}{|c|}{$\begin{array}{l}\text { Panel C.2. Constrained Model with } \\
\qquad \theta_{0}+\theta_{1}+\theta_{2}+\theta_{3}=1\end{array}$} \\
\hline Variable & $\begin{array}{l}\text { Volatile } \\
\text { Markers }\end{array}$ & $\begin{array}{c}\text { Consistent } \\
\text { Markers }\end{array}$ & $\begin{array}{c}\theta_{0} \\
\text { Difference }\end{array}$ & $\begin{array}{l}\text { Volatile } \\
\text { Markers }\end{array}$ & $\begin{array}{c}\text { Consistent } \\
\text { Markers }\end{array}$ & $\begin{array}{c}\theta_{0} \\
\text { Difference }\end{array}$ \\
\hline Intercept & $\begin{array}{c}0.0002 \\
(3.03)\end{array}$ & $\begin{array}{l}0.0000 \\
(1.59)\end{array}$ & & $\begin{array}{l}0.0000 \\
(-0.50)\end{array}$ & $\begin{array}{l}0.0000 \\
(-0.02)\end{array}$ & \\
\hline$R_{j, t}$ & $\begin{array}{l}0.9321 \\
(52.01)\end{array}$ & $\begin{array}{c}0.9949 \\
(400.52)\end{array}$ & $\begin{array}{c}-0.0628 \\
(4.09)\end{array}$ & $\begin{array}{l}0.9467 \\
(65.80)\end{array}$ & $\begin{array}{c}0.9965 \\
(484.73)\end{array}$ & $\begin{array}{c}-0.0498 \\
(4.03)\end{array}$ \\
\hline$R_{j, t-1}$ & $\begin{array}{c}0.0180 \\
(2.96)\end{array}$ & $\begin{array}{l}0.0031 \\
(1.68)\end{array}$ & & $\begin{array}{c}0.0326 \\
(3.78)\end{array}$ & $\begin{array}{l}0.0045 \\
(2.23)\end{array}$ & \\
\hline$R_{j, t-2}$ & $\begin{array}{c}-0.0072 \\
(-1.32)\end{array}$ & $\begin{array}{l}-0.0033 \\
(-2.04)\end{array}$ & & $\begin{array}{c}0.0079 \\
(1.16)\end{array}$ & $\begin{array}{c}-0.0021 \\
(-1.45)\end{array}$ & \\
\hline$R_{j, t-3}$ & $\begin{array}{c}-0.0013 \\
(-0.26)\end{array}$ & $\begin{array}{c}-0.0003 \\
(-0.24)\end{array}$ & & $\begin{array}{l}0.0128 \\
(2.43)\end{array}$ & $\begin{array}{c}0.0011 \\
(0.92)\end{array}$ & \\
\hline $\begin{array}{l}R^{2} \\
\# \text { of }\end{array}$ & $96.06 \%$ & $99.19 \%$ & & $94.85 \%$ & $99.17 \%$ & \\
\hline Funds & 68 & 96 & & 68 & 96 & \\
\hline
\end{tabular}




\section{Table VIII}

\section{Characteristics for the Volatile and Consistent Markers}

This table reports fund characteristics separately for the volatile and consistent markers. Fund characteristics are first averaged across all observations belonging to a particular fund and the statistics reported in this table are based on the cross-section of funds. Credit rating, issue size, and maturity are calculated as the weighted average of the bond characteristics comprising each portfolio each date, with weights equal to the market value of each bond position as reported by the fund. \% Non-Inv. Grade represents the \% weight of a fund portfolio in non-investment grade bonds. Bond Issue Size, Fund Family Assets, and Fund Assets are reported in millions.

\begin{tabular}{|c|c|c|c|c|c|c|c|c|}
\hline \multicolumn{9}{|c|}{ Consistent Markers } \\
\hline Characteristic & Minimum & $10^{\text {th }}$ Pctl & $25^{\text {th }}$ Pctl & Mean & Median & $75^{\text {th }}$ Pctl & $90^{\text {th }}$ Pctl & Maximum \\
\hline Bond Credit Rating & B- & $\mathrm{B}$ & $\mathrm{B}+$ & BBB- & $\mathrm{BBB}$ & A- & A- & A \\
\hline Bond Issue Size & 249 & 370 & 411 & 819 & 732 & 981 & 1,213 & 4,706 \\
\hline Bond Maturity & 4 & 6 & 7 & 9 & 8 & 9 & 12 & 20 \\
\hline$\%$ Non-Inv. Grade & 2.61 & 8.34 & 13.94 & 49.92 & 37.00 & 97.87 & 99.12 & 99.71 \\
\hline Family Assets & 65 & 402 & 1,087 & 21,495 & 4,155 & 13,508 & 43,216 & 196,130 \\
\hline \# of Family Funds & 1 & 5 & 12 & 66 & 38 & 83 & 172 & 522 \\
\hline Fund Assets & 22 & 49 & 109 & 460 & 213 & 563 & 1,131 & 6,301 \\
\hline Turnover (\%) & 8.12 & 48.35 & 74.66 & 187.18 & 128.44 & 249.16 & 426.88 & 750.58 \\
\hline Expense Ratio (\%) & 0.27 & 0.50 & 0.64 & 1.00 & 1.00 & 1.29 & 1.50 & 2.04 \\
\hline \multicolumn{9}{|c|}{ Volatile Markers } \\
\hline Characteristic & Minimum & $10^{\text {th }}$ Pctl & $25^{\text {th }}$ Pctl & Mean & Median & $75^{\text {th }}$ Pctl & $90^{\text {th }}$ Pctl & Maximum \\
\hline Bond Credit Rating & $\mathrm{B}+$ & $\mathrm{BB}+$ & $\mathrm{BBB}$ & $\mathrm{BBB}+$ & $\mathrm{BBB}+$ & A- & A & $A+$ \\
\hline Bond Issue Size & 363 & 449 & 542 & 774 & 773 & 985 & 1,085 & 1,315 \\
\hline Bond Maturity & 4 & 5 & 7 & 9 & 9 & 10 & 12 & 17 \\
\hline$\%$ Non-Inv. Grade & 0.26 & 5.78 & 9.47 & 31.81 & 24.33 & 44.45 & 74.33 & 99.40 \\
\hline Family Assets & 8 & 273 & 1,136 & 20,238 & 4,592 & 18,192 & 77,587 & 196,130 \\
\hline \# of Family Funds & 1 & 4 & 11 & 79 & 27 & 86 & 256 & 522 \\
\hline Fund Assets & 8 & 45 & 65 & 1,479 & 167 & 645 & 1,422 & 65,498 \\
\hline Turnover (\%) & 15.22 & 40.56 & 68.74 & 194.37 & 111.04 & 259.02 & 366.34 & 1701.78 \\
\hline Expense Ratio (\%) & 0.15 & 0.46 & 0.61 & 0.83 & 0.78 & 1.09 & 1.29 & 1.43 \\
\hline
\end{tabular}




\section{REFERENCES}

Agarwal, V., and N. Naik, 2000, Multi-period performance persistence analysis of hedge funds, Journal of Financial and Quantitative Analysis 35 (3), 327-342.

Agarwal, V., N. Daniel, and N. Naik, 2005, Why is Santa Claus so kind to hedge funds? The December bonanza puzzle! Unpublished working paper.

Amihud, Y., H. Mendelson, and B. Lauterbach, 1997, Market microstructure and securities values: Evidence from the Tel Aviv Stock Exchange, Journal of Financial Economics 45, 365-390.

Asness, C., R. Krail, and J. Liew, 2001, Do hedge funds hedge? Journal of Portfolio Management 28 (1), 6-19.

Bessembinder, H., W. Maxwell, and K. Venkataraman, 2006, Market transparency, liquidity externalities, and institutional trading costs in corporate bonds, Journal of Financial Economics 82 (2), 251-288.

Bhargava, R., A. Bose, and D. Dubofsky, 1998, Exploiting international stock market correlations with open-end international mutual funds, Journal of Business, Finance, and Accounting 25, 765-773.

Biaisa, B., L. Glosten, and C. Spatt, 2005, Market microstructure: A survey of microfoundations, empirical results, and policy implications, Journal of Financial Markets 8 (2) 217-264.

Bloomfield, R. and M. O'Hara, 1999, Market transparency: Who wins and who loses? Review of Financial Studies 12, 5-35.

Bollen, N. and V. Pool, 2006, Conditional return smoothing in the hedge fund industry, Journal of Financial and Quantitative Analysis, forthcoming.

Bollen, N. and V. Pool, 2007, Do hedge fund managers misreport returns? Evidence from the pooled distribution, Unpublished working paper.

Boudoukh, J., M. Richardson, M. Subrahmanyam, and R. Whitelaw, 2002, Stale prices and strategies for trading mutual funds, Financial Analysts Journal 58, 53-71.

Chalmers, J., R. Edelen, G. Kadlec, 2001, On the perils of financial intermediaries setting securities prices: the mutual fund wild card option, Journal of Finance 56 (6), 2209-2236.

Edwards, A., L. Harris, and M. Piwowar, 2007, Corporate bond market transparency and transaction costs, Journal of Finance 62 (3), 1421-1451. 
Fama, E., and J. MacBeth, 1973, Risk, return and equilibrium: Empirical tests, Journal of Political Economy 81, 607-636.

Getmansky, M., A. Lo, and I. Makarov, 2004, An econometric model of serial correlation and illiquidity in hedge fund returns, Journal of Financial Economics 74, 529-610.

Goetzmann, W., Z. Ivkovic, and K. Rouwenhorst, 2001, Day trading international mutual funds: Evidence and policy solutions, Journal of Financial and Quantitative Analysis 36, 287-309.

Goldstein, M., E. Hotchkiss, and E. Sirri, 2007, Transparency and liquidity: a controlled experiment on corporate bonds, Review of Financial Studies 20 (2), 235-273

Green, J., and C. Hodges, 2002, The dilution impact of daily fund flows on open-end mutual funds, Journal of Financial Economics 65, 131-158.

Investment Company Institute, ICI Mutual Insurance Company and the Independent Directors Council, An introduction to fair valuation, Spring 2005

Madhavan, A., 2000, Market microstructure, Journal of Financial Markets 3, 205-258.

Naik, N., A. Neuberger, and S. Viswanathan, 1999, Trade disclosure regulation in markets with negotiated trades, Review of Financial Studies 12 (4), 873-900.

Nelson, Matt. Evaluated security pricing services offerings have increased recently. Advanced Trading, March 23, 2007, available at http://www.advancedtrading.com/showArticle.jhtml;jsessionid=T0ABWVMTEFC1YQS NDLRCKH0CJUNN2JVN?articleID=198500315

Newey, W., and K. West, 1994, Automatic lag selection in covariance matrix estimation, The Review of Economic Studies, 61 (4), 631-653;

Pagano, M., and A. Roell, 1996, Transparency and liquidity: A comparison of auction and dealer markets with informed trading, Journal of Finance 51, 579-611.

Petersen, M., 2008, Estimating standard errors in finance panel data sets: Comparing approaches, Review of Financial Studies, forthcoming

PricewaterhouseCoopers LLP, Pricing and Valuation: Risks, Controls and Emerging Practices for Registered Investment Companies, Undated.

Pulliam, Susan, Randall Smith, and Michael Siconolf, 2007, U.S. investors face an age of murky pricing, The Wall Street Journal, October 12, A1.

Pulliam, Susan, 2007, Bonds' pricing is questioned in email trail, The Wall Street Journal, October 26, C1. 
Rahl, L., 2001, Capital market risk advisors NAV/fair value practices survey results, The Journal of Alternative Investments, 4 (3), 55-58.

Rogers, W., 1993, Regression standard errors in clustered samples, Stata Technical Bulletin 13, 19-23.

SEC Accounting Release Series 113, October 21, 1969.

SEC Accounting Release Series 118, Accounting for investment securities by registered investment companies, December 23, 1970.

The Bond Market Association and American Securitization Forum, 2006. An Analysis and Description of Pricing and Information Sources in the Securitized and Structured Finance Markets.

Zitzewitz, E., 2003, Who cares about shareholders? Arbitrage-proofing mutual funds, Journal of Law, Economics \& Organization 19 (2), 245-280. 